NBER WORKING PAPER SERIES

GLOBALIZATION, STRUCTURAL CHANGE AND PRODUCTIVITY GROWTH

Margaret S. McMillan

Dani Rodrik

Working Paper 17143

http://www.nber.org/papers/w17143

\author{
NATIONAL BUREAU OF ECONOMIC RESEARCH \\ 1050 Massachusetts Avenue \\ Cambridge, MA 02138 \\ June 2011
}

This is a paper prepared for a joint ILO-WTO volume. We are grateful to Marion Jansen for guidance and Inigo Verduzco for outstanding research assistance. Rodrik gratefully acknowledges financial support from IFPRI. McMillan gratefully acknowledges support from IFPRI's regional and country program directors for assistance with data collection. The views expressed herein are those of the authors and do not necessarily reflect the views of the National Bureau of Economic Research.

NBER working papers are circulated for discussion and comment purposes. They have not been peerreviewed or been subject to the review by the NBER Board of Directors that accompanies official NBER publications.

(C) 2011 by Margaret S. McMillan and Dani Rodrik. All rights reserved. Short sections of text, not to exceed two paragraphs, may be quoted without explicit permission provided that full credit, including (C) notice, is given to the source. 
Globalization, Structural Change and Productivity Growth

Margaret S. McMillan and Dani Rodrik

NBER Working Paper No. 17143

June 2011

JEL No. O1

\begin{abstract}
$\underline{\text { ABSTRACT }}$
Large gaps in labor productivity between the traditional and modern parts of the economy are a fundamental reality of developing societies. In this paper, we document these gaps, and emphasize that labor flows from low-productivity activities to high-productivity activities are a key driver of development. Our results show that since 1990 structural change has been growth reducing in both Africa and Latin America, with the most striking changes taking place in Latin America. The bulk of the difference between these countries' productivity performance and that of Asia is accounted for by differences in the pattern of structural change - with labor moving from low- to high-productivity sectors in Asia, but in the opposite direction in Latin America and Africa. In our empirical work, we identify three factors that help determine whether (and the extent to which) structural change contributes to overall productivity growth. In countries with a relatively large share of natural resources in exports, structural change has typically been growth reducing. Even though these "enclave" sectors usually operate at very high productivity, they cannot absorb the surplus labor from agriculture. By contrast, competitive or undervalued exchange rates and labor market flexibility have contributed to growth enhancing structural change.
\end{abstract}

\author{
Margaret S. McMillan \\ Tufts University \\ Department of Economics \\ 114a Braker Hall \\ Medford, MA 02155 \\ and International Food Policy Research Institute \\ and also NBER \\ margaret.mcmillan@tufts.edu \\ Dani Rodrik \\ John F. Kennedy School of Government \\ Harvard University \\ 79 JFK Street \\ Cambridge, MA 02138 \\ and NBER \\ dani_rodrik@harvard.edu
}




\section{Globalization, Structural Change, AND Productivity Growth}

$\underline{\text { Introduction }}$

One of the earliest and most central insights of the literature on economic development is that development entails structural change. The countries that manage to pull out of poverty and get richer are those that are able to diversify away from agriculture and other traditional products. As labor and other resources move from agriculture into modern economic activities, overall productivity rises and incomes expand. The speed with which this structural transformation takes place is the key factor that differentiates successful countries from unsuccessful ones.

Developing economies are characterized by large productivity gaps between different parts of the economy. Dual economy models à la W. Arthur Lewis have typically emphasized productivity differentials between broad sectors of the economy, such as the traditional (rural) and modern (urban) sectors. More recent research has identified significant differentials within modern, manufacturing activities as well. Large productivity gaps can exist even among firms and plants within the same industry. Whether between plants or across sectors, these gaps tend to be much larger in developing countries than in advanced economies. They are indicative of the allocative inefficiencies that reduce overall labor productivity.

The upside of these allocative inefficiencies is that they can potentially be an important engine of growth. When labor and other resources move from less productive to more productive activities, the economy grows even if there is no productivity growth within sectors. This kind of growth-enhancing structural change can be an important contributor to overall economic growth. High-growth countries are typically those that have experienced substantial growth-enhancing structural change. As we shall see, the bulk of the difference between Asia's 
recent growth, on the one hand, and Latin America's and Africa’s, on the other, can be explained by the variation in the contribution of structural change to overall labor productivity. Indeed, one of the most striking findings of this paper is that in many Latin American and Sub-Saharan African countries, broad patterns of structural change have served to reduce rather than increase economic growth since 1990 .

Developing countries, almost without exception, have become more integrated with the world economy since the early 1990s. Industrial tariffs are lower than they ever have been and foreign direct investment flows have reached new heights. Clearly, globalization has facilitated technology transfer and contributed to efficiencies in production. Yet the very diverse outcomes we observe among developing countries suggest that the consequences of globalization depend on the manner in which countries integrate into the global economy. In several cases - most notably China, India, and some other Asian countries - globalization’s promise has been fulfilled. High-productivity employment opportunities have expanded and structural change has contributed to overall growth. But in many other cases - in Latin America and Sub-Saharan Africa - globalization appears not to have fostered the desirable kind of structural change. Labor has moved in the wrong direction, from more productive to less productive activities, including, most notably, informality.

This conclusion would seem to be at variance with a large body of empirical work on the productivity-enhancing effects of trade liberalization. For example, study after study shows that intensified import competition has forced manufacturing industries in Latin America and elsewhere to become more efficient by rationalizing their operations. ${ }^{1}$ Typically, the least productive firms have exited the industry, while remaining firms have shed “excess labor.” It is

\footnotetext{
${ }^{1}$ See for example Cavalcanti et al (2003), Esclava et al (2007), Fernandez et al (2007), McMillan et al (2004), Paus et al (2003) and Pavcnik (2002).
} 
evident that the top tier of firms has closed the gap with the technology frontier - in Latin America and Africa, no less than in East Asia. However, the question left unanswered by these studies is what happens to the workers who are thereby displaced. In economies that don't exhibit large inter-sectoral productivity gaps or high and persistent unemployment, labor displacement would not have important implications for economy-wide productivity. In developing economies, on the other hand, the prospect that the displaced workers would end up in even lower-productivity activities (services, informality) cannot be ruled out. That is indeed what seems to have typically happened in Latin America and Africa. An important advantage of the broad, economy-wide approach we take in this paper is that it is able to capture changes in inter-sectoral allocative efficiency as well as improvements in within-industry productivity.

In our empirical work, we identify three factors that help determine whether (and the extent to which) structural change goes in the right direction and contributes to overall productivity growth. First, economies with a revealed comparative advantage in primary products are at a disadvantage. The larger the share of natural resources in exports, the smaller the scope of productivity-enhancing structural change. The key here is that minerals and natural resources do not generate much employment, unlike manufacturing industries and related services. Even though these "enclave” sectors typically operate at very high productivity, they cannot absorb the surplus labor from agriculture.

Second, we find that countries that maintain competitive or undervalued currencies tend to experience more growth-enhancing structural change. This is in line with other work that documents the positive effects of undervaluation on modern, tradable industries (Rodrik 2008). Undervaluation acts as a subsidy on those industries and facilitates their expansion. 
Finally, we also find evidence that countries with more flexible labor markets experience greater growth-enhancing structural change. This also stands to reason, as rapid structural change is facilitated when labor can flow easily across firms and sectors. By contrast, we do not find that other institutional indicators, such as measures of corruption or the rule of law, play a significant role.

The remainder of the paper is organized as follows. Section II describes our data and presents some stylized facts on economy-wide gaps in labor productivity. The core of our analysis is contained in section III, where we discuss patterns of structural change in Africa, Asia and Latin America since 1990. Section IV focuses on explaining why structural change has been growth-enhancing in some countries and growth-reducing in others. Section V offers final comments. The Appendix provides further details about the construction of our data base.

\section{The data and some stylized facts}

Our data base consists of sectoral and aggregate labor productivity statistics for 38 countries, covering the period up to 2005. Of the countries included, twenty-nine are developing countries and nine are high-income countries. The countries and their geographical distribution are shown in Table 1, along with some summary statistics.

In constructing our data, we took as our starting point the Groningen Growth and Development Center (GGDC) data base, which provides employment and real valued added statistics for 27 countries disaggregated into 10 sectors (Timmer and de Vries, 2007; 2009). ${ }^{2}$ The GGDC dataset does not include any African countries or China. Therefore, we collected our

\footnotetext{
${ }^{2}$ The original GGDC sample also includes West Germany, but we dropped it from our sample due to the truncation of the data after 1991. The latest update available for each country was used. Data for Latin American and Asian countries came from the June 2007 update, while data for the European countries and the U.S. came from the October 2008 update.
} 
own data from national sources for an additional eleven countries, expanding the sample to cover several African countries, China and Turkey (another country missing from the GGDC sample). In order to maintain consistency with the GGDC Database data, we followed, as closely as possible, the procedures on data compilation followed by the GGDC authors. ${ }^{3}$ For purposes of comparability, we combined two of the original sectors (Government Services and Community, Social and Personal Services) into a single one, reducing the total number of sectors to nine. We converted local currency value added at 2000 prices to dollars using 2000 PPP exchange rates. Labor productivity was computed by dividing each sector's value added by the corresponding level of sectoral employment. We provide more details on our data construction procedures in the Appendix. The sectoral breakdown we shall use in the rest of the paper is shown in Table 2.

A big question with data of this sort is how well they account for the informal sector. Our data for value added come from national accounts, and as mentioned by Timmer and de Vries (2007), the coverage of such data varies from country to country. While all countries make an effort to track the informal sector, obviously the quality of the data can vary greatly. On employment, Timmer and de Vries' strategy is to rely on household surveys (namely, population censuses) for total employment levels and their sectoral distribution, and use labor force surveys for the growth in employment between census years. Census data and other household surveys tend to have more complete coverage of informal employment. In short, a rough characterization would be that the employment numbers in our dataset broadly coincide with actual employment levels regardless of formality status, while the extent to which value added data include or exclude the informal sector heavily depends on the quality of national sources.

\footnotetext{
${ }^{3}$ For a detailed explanation of the protocols followed to compile the GGDC 10-Sector Database, the reader is referred to the "Sources and Methods" section of the database's web page: http://www.ggdc.net/databases/10_sector.htm.
} 
The countries in our sample range from Malawi, with an average labor productivity of $\$ 1,354$ (at 2000 PPP dollars), to the United States, where labor productivity is more than fifty times as large $(\$ 70,235)$. They include nine African countries, nine Latin American countries, ten developing Asian countries, one Middle Eastern country, and nine high-income countries. China is the country with the fastest overall productivity growth rate (8.9 percent per annum between 1990 and 2005). At the other extreme, Kenya, Zambia, Malawi, and Venezuela have experienced negative productivity growth rates over the same period.

As Table 1 shows, labor productivity gaps between different sectors are typically very large in developing countries. This is particularly true for poor countries with mining enclaves, where few people tend to be employed at very high labor productivity. In Malawi, for example, labor productivity in mining is 136 times larger than that in agriculture! In fact, if only all of Malawi's workers could be employed in mining, Malawi's labor productivity would match that of the United States. Of course, mining cannot absorb many workers, and neither would it make sense to invest in so much physical capital across the entire economy.

It may be more meaningful to compare productivity levels across sectors with similar potential to absorb labor, and here too the gaps can be quite large. We see a typical pattern in Turkey, which is a middle-income country with still a large agricultural sector (Figure 1). Productivity in construction is more than twice the productivity in agriculture, and productivity in manufactures is almost three times as large. The average manufactures-agriculture productivity ratio is 2.3 in Africa, 2.8 in Latin America, and 3.9 in Asia. Note that the productivity-disadvantage of agriculture does not seem to be largest in the poorest countries, a point to which we will return below. 
On the whole, however, inter-sectoral productivity gaps are clearly a feature of underdevelopment. They are widest for the poorest countries in our sample and tend to diminish as a result of sustained economic growth. Figure 2 shows how a measure of economy-wide productivity gaps, the coefficient of variation of the log of sectoral labor productivities, declines over the course of development. The relationship between this measure and the average labor productivity in the country is negative and highly statistically significant. The figure underscores the important role that structural change plays in producing convergence, both within economies and across poor and rich countries. The movement of labor from low-productivity to highproductivity activities raises economy-wide labor productivity. Under diminishing marginal products, it also brings about convergence in economy-wide labor productivities.

The productivity gaps described here refer to differences in average labor productivity. When markets work well and structural constraints don't bind, it is productivities at the margin that should be equalized. Under a Cobb-Douglas production function specification, the marginal productivity of labor is the average productivity multiplied by the labor share. So if labor shares differ greatly across economic activities comparing average labor productivities can be misleading. The fact that average productivity in public utilities is so high (see Table 2), for example, may simply indicate that the labor share of value added in this capital-intensive sector is quite small. But in the case of other sectors it is not clear that there is a significant bias. Once the share of land is taken into account, for example, it is not obvious that the labor share in agriculture is significantly lower than in manufacturing (Mundlak et al., 2008). So the 2-4-fold differences in average labor productivities between manufacturing and agriculture do point to large gaps in marginal productivity. 
Another way to emphasize the contribution of structural change is to document how much of the income gap between rich and poor countries is accounted for by differences in economic structure as opposed to differences in productivity levels within sectors. Since even poor economies have some industries that operate at high level of productivity, it is evident that these economies would get a huge boost if such industries could employ a much larger share of the economy's labor force. The same logic applies to broad patterns of structural change as well, captured by our 9-sector classification.

Consider the following thought experiment. Suppose that sectoral productivity levels in the poor countries were to remain unchanged, but that the inter-sectoral distribution of employment matched what we observe in the advanced economies. ${ }^{4}$ This would mean that developing countries would employ a lot fewer workers in agriculture and a lot more in their modern, productive sectors. We assume that these changes in employment patterns could be achieved without any change (up or down) in productivity levels within individual sectors. What would be the consequences for economy-wide labor productivity? Figures 3 and 4 show the results for the non-African and African samples, respectively.

The hypothetical gains in overall productivity from sectoral reallocation, along the lines just described, are quite large, especially for the poorer countries in the sample. India's average productivity would more than double, while China's would almost triple (Figure 3). The potential gains are particularly large for several African countries, which is why those countries are shown on a separate graph using a different scale. Ethiopia’s productivity would increase six-fold, Malawi's seven-fold, and Senegal's eleven-fold! Of course these numbers are only indicative of the extent of dualism that marks poor economies and should not be taken literally.

\footnotetext{
4 The inter-sectoral distribution of employment for high-income countries is calculated as the simple average of each sector's employment share across the high-income sample.
} 
Taking developing countries as a whole, as much as a fifth of the productivity gap that separates them from the advanced countries would be eliminated by the kind of reallocation considered here.

Traditional dual-economy models emphasize the productivity gaps between the agricultural (rural) and non-agricultural (urban) parts of the economy. Indeed, the summary statistics in Table 1 show that agriculture is typically the lowest-productivity activity in the poorest economies. Yet another interesting stylized fact of the development process revealed by our data is that the productivity gap between the agricultural and non-agricultural sectors behaves non-monotonically during economic growth. The gap first increases and then falls, so that the ratio of agricultural to non-agricultural productivity exhibits a U-shaped pattern as the economy develops.

This is shown in Figure 5, where the productivity ratio between agriculture and nonagriculture (i.e., the rest of the economy) is graphed against the (log) of average labor productivity for our full panel of observations. A quadratic curve fits the data very well, and both terms of the equation are statistically highly significant. The fitted quadratic indicates that the turning point comes at an economy-wide productivity level of around $\$ 9,000$ ( = exp(9.1)) per worker. This corresponds to a development level somewhere between that of India and China in 2005.

We can observe this U-shaped relationship also over time within countries, as is shown in Figure 6 which collates the time-series observations for three countries at different stages of development (India, Peru, and France). India, which is the poorest of the three countries, is on the downward sloping part of the curve. As its economy has grown, the gap between agricultural and non-agricultural productivity has increased (and the ratio of agricultural to non-agricultural 
productivity has fallen). France, a wealthy country, has seen the opposite pattern. As income has grown, there has been greater convergence in the productivity levels of the two types of sectors. Finally, Peru represents an intermediate case, having spent most of its recent history around the minimum-point at the bottom of the U-curve.

A basic economic logic lies behind the U-curve. A very poor country has few modern industries in the non-agricultural parts of the economy. So even though agricultural productivity is very low, there isn’t a large gap yet with the rest of the economy. Economic growth typically happens with investments in the modern, urban parts of the economy. As these sectors expand, a wider gap begins to open between the traditional and modern sectors. The economy becomes more "dual." At the same time, labor begins to move from traditional agriculture to the modern parts of the economy, and this acts as a countervailing force. Past a certain point, this second force becomes the dominant one, and productivity levels begin to converge within the economy. This story highlights the two key dynamics in the process of structural transformation: the rise of new industries (i.e., economic diversification) and the movement of resources from traditional industries to these newer ones. Without the first, there is little that propels the economy forward. Without the second, productivity gains don't diffuse in the rest of the economy. We end this section by relating our stylized facts to some other recent strands of the development literature that have focused on productivity gaps and misallocation of resources. There is a growing literature on productive heterogeneity within industries. Most industries in the developing world are a collection of smaller, typically informal firms that operate at low levels of productivity along with larger, highly productive firms that are better organized and use more advanced technologies. Various studies by the McKinsey Global Institute have

\footnotetext{
${ }^{5}$ See Kuznets (1955) for an argument along these lines. However, Kuznets conjectured that the gap between agriculture and industry would keep increasing, rather than close down as we see here.
} 
documented in detail the duality within industries. For example, MGI's analysis of a number of Turkish industries finds that on average the modern segment of firms is almost three times as productive as the traditional segment (MGI 2003). Bartelsman et al. (2006) and Hsieh and Klenow (2009) have focused on the dispersion in total factor productivity across plants, the former for a range of advanced and semi-industrial economies and the latter for China and India. Hsieh and Klenow's (2009) findings indicate that between a third and a half of the gap in these countries' manufacturing TFP vis-à-vis the U.S. would be closed if the "excess” dispersion in plant productivity were removed. There is also a substantial empirical literature, mentioned in the introduction, which underscores the allocative benefits of trade liberalization within manufacturing: as manufacturing firms are exposed to import competition, the least productive among them lose market share or shut down, raising the average productivity of those that remain.

There is an obvious parallel between these studies and ours. Our data are too broad-brush to capture the finer details of misallocation within individual sectors and across plants and firms. But a compensating factor is that we may be able to track the economy-wide effects of reallocation - something that analyses that remain limited to manufacturing cannot do. Improvements in manufacturing productivity that come at the expense of greater inter-sectoral misallocation - say because employment shifts from manufacturing to informality - need not be a good bargain. In addition, we are able to make comparisons among a larger sample of developing countries. So this paper should be viewed as a complement to the plant- or firm-level studies. 


\section{Patterns of structural change and productivity growth}

We now describe the pace and nature of structural change in developing economies over the period 1990 to 2005. We focus on this period for two reasons. First, this is the most recent period, and one where globalization has exerted a significant impact on all developing nations. It will be interesting to see how different countries have handled the stresses and opportunities of advanced globalization. And second, this is the period for which we have the largest sample of developing countries.

We will demonstrate that there are large differences in patterns of structural change across countries and regions and that these account for the bulk of the differential performance between successful and unsuccessful countries. In particular, while Asian countries have tended to experience productivity-enhancing structural change, both Latin America and Africa have experienced productivity-reducing structural change. In the next section we will turn to an analysis of the determinants of structural change. In particular, we are interested in understanding why some countries have the right kind of structural change while others have the wrong kind.

A. Defining the contribution of structural change

Labor productivity growth in an economy can be achieved in one of two ways. First, productivity can grow within economic sectors through capital accumulation, technological change, or reduction of misallocation across plants. Second, labor can move across sectors, from low-productivity sectors to high-productivity sectors, increasing overall labor productivity in the economy. This can be expressed using the following decomposition: 


$$
\Delta Y_{t}=\sum_{i=n} \theta_{i, t-k} \Delta y_{i, t}+\sum_{i=n} y_{i, t} \Delta \theta_{i, t}
$$

where $Y_{t}$ and $y_{i, t}$ refer to economy-wide and sectoral labor productivity levels, respectively, and $\theta_{i, t}$ is the share of employment in sector $i$. The $\Delta$ operator denotes the change in productivity or employment shares between t-k and t. The first term in the decomposition is the weighted sum of productivity growth within individual sectors, where the weights are the employment share of each sector at the beginning of the time period. We will call this the "within" component of productivity growth. The second term captures the productivity effect of labor reallocations across different sectors. It is essentially the inner product of productivity levels (at the end of the time period) with the change in employment shares across sectors. We will call this second term the "structural change" term. When changes in employment shares are positively correlated with productivity levels, this term will be positive, and structural change will increase economy-wide productivity growth.

The decomposition above clarifies how partial analyses of productivity performance within individual sectors (e.g., manufacturing) can be misleading when there are large differences in labor productivities $\left(y_{i, t}\right)$ across economic activities. In particular, a high rate of productivity growth within an industry can have quite ambiguous implications for overall economic performance if the industry's share of employment shrinks rather than expands. If the displaced labor ends up in activities with lower productivity, economy-wide growth will suffer and may even turn negative.

B. Structural change in Latin America: 1950-2005 
Before we present our own results, we illustrate this possibility with a recent finding on Latin America. When the Inter-American Development Bank recently analyzed the pattern of productivity change in the region since 1950, using the same Timmer and de Vries $(2007,2009)$ dataset and a very similar decomposition, it uncovered a striking result, shown in Figure 7. Between 1950 and 1975, Latin America experienced rapid (labor) productivity growth of almost 4 percent per annum, roughly half of which was accounted for by structural change. Then the region went into a debt crisis and experienced a "lost decade," with productivity growth in the negative territory between 1975 and 1990. Latin America returned to growth after 1990, but productivity growth never regained the levels seen before 1975 . This is due entirely to the fact that the contribution of structural change has now turned negative. The "within" component of productivity growth is virtually identical in the two periods 1950-1975 and 1990-2005 (at 1.8 percent per annum). But the structural change component went from 2 percent during 19501975 to -0.2 percent in 1990-2005, an astounding reversal in the course of a few decades.

This is all the more surprising in light of the commonly accepted view that Latin America's policies and institutions improved significantly as a result of the reforms of the late 1980s and early 1990s. Argentina, Brazil, Mexico, Chile, Colombia, and most of the other economies got rid of high inflation, brought fiscal deficits under control, turned over monetary policy to independent central banks, eliminated financial repression, opened up their economies to international trade and capital flows, privatized state enterprises, reduced red tape and most subsidies, and gave markets freer rein in general. Those countries which had become dictatorships during the 1970s experienced democratic transitions, while others significantly improved governance as well. Compared to the macroeconomic populism and protectionist, 
import-substitution policies that had prevailed until the end of the 1970s, this new economic environment was expected to yield significantly enhanced productivity performance.

The sheer scale of the contribution of structural change to this reversal of fortune has been masked by microeconomic studies that record significant productivity gains for individual plants or industries, and further, find these gains to be strongly related to post-1990 policy reforms. In particular, studies after studies have shown that the intensified competition brought about by trade liberalization has forced manufacturing industries to become more productive (see for example Pavcnik 2000, Paus et al. 2003, Cavalcanti Ferreira and Rossi 2003, Fernandes 2007, and Esclava et al. 2009). A key mechanism that these studies document is what's called "industry rationalization:” the least productive firms exit the industry, and remaining firms shed “excess labor.”

The question left unanswered is what happens to the workers who are thereby displaced. In economies which do not exhibit large inter-sectoral productivity gaps, labor displacement would not have important implications for economy-wide productivity. Clearly, this is not the case in Latin America. The evidence in Figure 7 suggests instead that displaced workers may have ended up in less productive activities. In other words, rationalization of manufacturing industries may have come at the expense of inducing growth-reducing structural change.

An additional point that needs making is that these calculations (as well as the ones we report below) do not account for unemployment. For a worker, unemployment is the least productive status of all. In most Latin American countries unemployment has trended upwards since the early 1990s, rising by several percentage points of the labor force in Argentina, Brazil, and Colombia. Were we to include the displacement of workers into unemployment, the 
magnitude of the productivity-reducing structural change experienced by the region would look even more striking. ${ }^{6}$

Figure 7 provides interesting new insight on what has held Latin American productivity growth back in recent years, despite apparent technological progress in many of the advanced sectors of the region's economies. But it also raises a number of questions. In particular, was this experience a general one across all developing countries, and what explains it? If there are significant differences across countries in this respect, what are the drivers of these differences?

C. Patterns of structural change by region

We present our central findings on patterns of structural change in Figure 8. Simple averages are presented for the 1990-2005 period for four groups of countries: Latin America, Sub-Saharan Africa, Asia, and high-income countries. ${ }^{7}$

We note first that structural change has made very little contribution (positive or negative) to the overall growth in labor productivity in the high-income countries in our sample. This is as expected, since we have already noted the disappearance of inter-sectoral productivity gaps during the course of development. Even though many of these advanced economies have experienced significant structural change during this period, with labor moving predominantly from manufacturing to service industries, this (on its own) has made little difference to productivity overall. What determines economy-wide performance in these economies is, by and large, how productivity fares in each individual sector.

\footnotetext{
${ }^{6}$ We have undertaken some calculations along these lines, including “unemployment” as an additional sector in the decomposition. Preliminary calculations indicate that the rise in unemployment between 1990 and 2005 worsens the structural change term by an additional 0.2 percentage points. We hope to report results on this in future work.

${ }^{7}$ Even though Turkey is in our dataset, this country has not been included in this and the next figure because it is the only Middle Eastern country in our sample.
} 
The developing countries exhibit a very different picture. Structural change has played an important role in all three regions. But most striking of all is the differences among the regions. In both Latin America and Africa, structural change has made a sizable negative contribution to overall growth, while Asia is the only region where the contribution of structural change is positive. (The results for Latin America do not match exactly those in Figure 7 because we have applied a somewhat different methodology when computing the decomposition from that used by Pages et al., 2010. ${ }^{8}$ ) We note again that these computations do not take into account unemployment. Latin America (certainly) and Africa (possibly) would look considerably worse if we accounted for the rise of unemployment in these regions.

Hence, the curious pattern of growth-reducing structural change that we observed above for Latin America is repeated in the case of Africa. This only deepens the puzzle as Africa is substantially poorer than Latin America. If there is one region where we would have expected the flow of labor from traditional to modern parts of the economy to be an important driver of growth, a la dual-economy models, that surely is Africa. The disappointment is all the greater in light of all of the reforms that African countries have undergone since the late 1980s. Yet labor seems to have moved from high- to low- productivity activities on average, reducing Africa's growth by 1.3 percentage points per annum on average (Table 3). Since Asia has experienced growth-enhancing structural change during the same period, it is difficult to ascribe Africa's and Latin America's performance solely to globalization or other external determinants. Clearly, country-specific forces have been at work as well.

Differential patterns of structural change in fact account for the bulk of the difference in regional growth rates. This can be seen by checking the respective contributions of the "within"

\footnotetext{
${ }^{8}$ We fixed some data discrepancies and used a 9-sector disaggregation to compute the decomposition rather than IDB's 3-sector disaggregation. See the data appendix for more details.
} 
and "structural change" components to the differences in productivity growth in the three regions. Asia’s labor productivity growth in 1990-2005 exceeded Africa’s by 3 percentage points per annum and Latin America's by 2.5 percentage points. Of this difference, the structural change term accounts for 1.84 points (61\%) in Africa and 1.45 points (58\%) in Latin America. We saw above that the decline in the contribution of structural change was a key factor behind the deterioration of Latin American productivity growth since the 1960s. We now see that the same factor accounts for the lion's share of Latin America's (as well as Africa's) underperformance relative to Asia.

In other words, where Asia has outshone the other two regions is not so much in productivity growth within individual sectors, where performance has been broadly similar, but in ensuring that the broad pattern of structural change contributes to, rather than detracts from, overall economic growth. As Table 4 shows, some mineral-exporting African countries such as Zambia and Nigeria have in fact experienced very high productivity growth at the level of individual sectors, as have many Latin American countries. But when individual countries are ranked by the magnitude of the structural change term, it is Asian countries that dominate the top of the list.

The regional averages we have discussed so far are unweighted averages across countries that do not take into account differences in country size. When we compute a regional average that sums up value added and employment in the same sector across countries, giving more weight to larger countries, we obtain the results shown in Figure 9. The main difference now is that we get a much larger "within" component for Asia, an artifact of the predominance of China in the weighted sample. Also, the negative structural change component turns very slightly positive in Latin America, indicating that labor flows in the larger Latin American countries 
haven't gone as much in the wrong direction as they have in the smaller ones. Africa still has a large and negative structural change term. Asia once more greatly outdoes the other two developing regions in terms of the contribution of structural change to overall growth.

D. More details on individual countries and sectors

The presence of growth-reducing structural change on such a scale is a surprising phenomenon that calls for further scrutiny. We can gain further insight into our results by looking at the sectoral details for specific countries. We note that growth-reducing structural change indicates that the direction of labor flows is negatively correlated with (end-of-period) labor productivity in individual sectors. So for selected countries we plot the (end-of-period) relative productivity of sectors $\left(y_{i, t} / Y_{t}\right)$ against the change in their employment share $\left(\Delta \theta_{i, t}\right)$ between 1990 and 2005. The relative size of each sector (measured by employment) is indicated by the circles around each sector's label in the scatter plots. The next six figures (Figures 10-15) show sectoral detail for two countries each from Latin America, Africa, and Asia.

Argentina shows a particularly clear-cut case of growth-reducing structural change (Figure 10). The sector with the largest relative loss in employment is manufacturing, which also happens to be the largest sector among those with above-average productivity. Most of this reduction in manufacturing employment took place during the 1990s, under the Argentine experiment with hyper-openness. Even though the decline in manufacturing was halted and partially reversed during the recovery from the financial crisis of 2001-2002, this was not enough to change the overall picture for the period 1990-2005. By contrast, the sector experiencing the largest employment gain is community, personal, and government services, which has a high 
level of informality and is among the least productive. Hence the sharply negative slope of the Argentine scatter plot.

Brazil shows a somewhat more mixed picture (Figure 11). The collapse in manufacturing employment was not as drastic as in Argentina (relatively speaking), and it was somewhat counterbalanced by the even larger contraction in agriculture, a significantly below-average productivity sector. On the other hand, the most rapidly expanding sectors were again relatively unproductive non-tradable sectors such as personal and community services and wholesale and retail trade. On balance, the Brazilian slope is slightly negative, indicating a small growthreducing role for structural change.

The African cases of Nigeria and Zambia show negative structural change for somewhat different reasons (Figures 12 and 13). In both countries, the employment share of agriculture has increased significantly (alongside with community and government services in Nigeria). By contrast, manufacturing and relatively productive tradable services have experienced a contraction - a remarkable anomaly for countries at such low levels of development, in which these sectors are quite small to begin with. The expansion of agricultural employment in Zambia is particularly large - more than 20 percentage points of total employment between 1990 and 2005, if the numbers are to be believed. These figures indicate a veritable exodus from the rest of the economy back to agriculture, where labor productivity is roughly half of what it is elsewhere. Thurlow and Wobst (2005, pp. 24-25) describe how the decline of formal employment in Zambian manufacturing during the 1990s as a result of import liberalization led to many low-skilled workers ending up in agriculture.

Africa exhibits a lot of heterogeneity, however, and the expansion of agricultural employment that we see in Nigeria and Zambia is not a common phenomenon across the 
continent. In general the sector with the largest relative loss in employment is wholesale and retail trade where productivity is higher (in Africa) than the economy-wide average. The expansion of employment in manufacturing has been meager, at around one quarter of one percent over the fifteen year period. The sector experiencing the largest employment gain tends to be community, personal, and government services, which has a high level of informality and is the least productive.

Ghana, Ethiopia and Malawi are three countries that have experienced growth-enhancing structural change. In all three cases, the share of employment in the agricultural sector has declined while the share of employment in the manufacturing sector has increased. However, labor productivity in manufacturing remains notably low in both Ghana and Ethiopia.

Compare the African cases now to India, which has experienced significant growthenhancing structural change since 1990. As Figure 15 shows, labor has moved predominantly from very low-productivity agriculture to modern sectors of the economy, including notably manufacturing. India is one of the poorest countries in our sample, so its experience need not be representative. But another Asian country, Thailand, shows very much the same pattern (Figure 16). In fact, the magnitude of growth-enhancing structural change in Thailand has been phenomenal, with agriculture's employment share declining by some 20 percentage points and manufacturing experiencing significant gains.

Not all Asian countries exhibit this kind of pattern. South Korea and Singapore, in particular, look more like Latin American countries in that high-productivity manufacturing sectors have shrunk in favor of some relatively lower-productivity service activities. But in both of these cases, very rapid "within” productivity growth has more than offset the negative contribution from structural change. That has not happened in Latin America. Moreover, a 
contraction in the share of the labor force in manufacturing is not always a bad thing. For example, in the case of Hong Kong, the share of the labor force in manufacturing fell by more than $20 \%$. But because productivity in manufacturing is lower than productivity in most other sectors, this shift has produced growth-enhancing structural change.

\section{What explains these patterns of structural change?}

All developing countries in our sample have become more "globalized" during the time period under consideration. They have phased out remaining quantitative restrictions on imports, slashed tariffs, encouraged direct foreign investment and exports, and, in many cases, opened up to cross-border financial flows. So it is natural to think that globalization has played an important behind-the-scenes role in driving the patterns of structural change we have documented above.

However, it is also clear that this role cannot have been a direct, straightforward one. For one thing, what stands out in the findings described previously is the wide range of outcomes: some countries (mostly in Asia) have continued to experience rapid, productivity-enhancing structural change, while others (mainly in Africa and Latin America) have begun to experience productivity-reducing structural change. A common external environment cannot explain such large differences. Second, as important as agriculture, mining, and manufacturing are, a large part - perhaps a majority - of jobs are still provided by non-tradable service industries. So whatever contribution globalization has made, it must depend heavily on local circumstances, choices made by domestic policy makers, and domestic growth strategies.

We have noted above the costs that premature de-industrialization have on economywide productivity. Import competition has caused many industries to contract and release labor 
to less productive activities, such as agriculture and informality. One important difference among countries may be the degree to which they are able to manage such downsides. A notable feature of Asian-style globalization is that it has had a two-track nature: many import-competing activities have continued to receive support while new, export-oriented activities were spawned. For example, until the mid-1990s, China had liberalized its trade regime at the margin only. Firms in special economic zones (SEZs) operated under free-trade rules, while domestic firms still operated behind high trade barriers. State enterprises still continue to receive substantial support. In an earlier period, South Korea and Taiwan pushed their firms onto world markets by subsidizing them heavily, and delayed import liberalization until domestic firms could stand on their feet. Strategies of this sort have the advantage, from the current perspective, of ensuring that labor remains employed in firms that might otherwise get decimated by import competition. Such firms may not be the most efficient in the economy, but they often provide jobs at productivity levels that exceed their employees' next-best alternative (i.e., informality or agriculture).

A related issue concerns the real exchange rate. Countries in Latin America and Africa have typically liberalized in the context of overvalued currencies - driven either by disinflationary monetary policies or by large foreign aid inflows. Overvaluation squeezes tradable industries further, damaging especially the more modern ones in manufacturing that operate at tight profit margins. Asian countries, by contrast, have often targeted competitive real exchange rates with the express purpose of promoting their tradable industries. Below, we will provide some empirical evidence on the role played by the real exchange rate in promoting desirable structural change. 
Globalization promotes specialization according to comparative advantage. Here there is another potentially important difference among countries. Some countries - many in Latin America and Africa - are well-endowed with natural resources and primary products. In these economies, opening up to the world economy reduces incentives to diversify towards modern manufactures and reinforces traditional specialization patterns. As we have seen, some primary sectors such as minerals do operate at very high levels of labor productivity. The problem with such activities, however, is that they have a very limited capacity to generate substantial employment. So in economies with a comparative advantage in natural resources, we expect the positive contribution of structural change associated with participation in international markets to be limited. Asian countries, most of which are well endowed with labor but not natural resources, have a natural advantage here. The regression results to be presented below bear this intuition out.

The rate at which structural change in the direction of modern activities takes place can also be influenced by ease of entry and exit into industry and by the flexibility of labor markets. Ciccone and Papaioannou (2008) show that intersectoral reallocation within manufacturing industries is slowed down by entry barriers. When employment conditions are perceived as "rigid,” say because of firing costs that are too high, firms are likely to respond to new opportunities by upgrading plant and equipment (capital deepening) rather than by hiring new workers. This slows down the transition of workers to modern economic activities. This hypothesis also receives some support from the data.

We now present the results of some exploratory regressions aimed at uncovering the main determinants of differences across countries in the contribution of structural change (Table 5). We regress the structural-change term over the 1990-2005 period (the second term in 
equation (1), annualized in percentage terms) on a number of plausible independent variables. We view these regressions as a first pass through the data, rather than a full-blown causal analysis.

We begin by examining the role of initial structural gaps. Clearly, the wider those gaps, the larger the room for growth-enhancing structural change for standard dual-economy model reasons. We proxy these gaps by agriculture's employment share at the beginning of the period (1990). Somewhat surprisingly, even though this variable enters the regression with a positive coefficient, it falls far short of statistical significance (column 1). The implication is that domestic convergence, just like convergence with rich countries, is not an unconditional process. Starting out with a significant share of your labor force in agriculture may increase the potential for structural-change induced growth, but the mechanism is clearly not automatic.

Note that we have included regional dummies (in this and all other specifications), with Asia as the excluded category. The statistically significant coefficients on Latin America and Africa (both negative) indicate that the regional differences we have discussed previously are also meaningful in a statistical sense.

We next introduce the share of a country's exports that is accounted for by raw materials, as an indicator of comparative advantage. This indicator enters with a negative coefficient, and is highly significant (column 2). There is a very strong and negative association between a country's reliance on primary products and the rate at which structural change contributes to growth. Countries that specialize in primary products are at a distinct disadvantage.

We note two additional points about column (2). First, agriculture's share in employment now turns statistically significant. This indicates the presence of conditional convergence: conditional on not having a strong comparative advantage in primary products, starting out with 
a large countryside of surplus workers does help. Second, once the comparative advantage indicator is entered, the coefficients on regional dummies are slashed and they are no longer statistically significant. In other words, comparative advantage and the initial agricultural share can jointly fully explain the large differences in average performance across regions. Countries that do well are those that start out with a lot of workers in agriculture but do not have a strong comparative advantage in primary products. That most Asian countries fit this characterization explains the Asian difference we have highlighted above.

For trade/currency practices, we use a measure of the undervaluation of a country’s currency, based on a comparison of price levels across countries (after adjusting for the BalassaSamuelson effect; see Rodrik 2008). For labor markets, we use the employment rigidity index from the World Bank’s World Development Indicators data base. The results in columns (3)-(5) indicate that both of these indicators enter the regression with the expected sign and are statistically significant. Undervaluation promotes growth-enhancing structural change, while employment rigidity inhibits it.

We have tried a range of other specifications and additional regressors, including income levels, demographic indicators, institutional quality, and tariff levels. But none of these variables have turned out to be consistently significant.

\section{Concluding comments}

Large gaps in labor productivity between the traditional and modern parts of the economy are a fundamental reality of developing societies. In this paper, we have documented these gaps, and emphasized that labor flows from low-productivity activities to high-productivity activities are a key driver of development. 
Our results show that since 1990 structural change has been growth reducing in both Africa and Latin America, with the most striking changes taking place in Latin America. The bulk of the difference between these countries' productivity performance and that of Asia is accounted for by differences in the pattern of structural change - with labor moving from low- to high-productivity sectors in Asia, but in the opposite direction in Latin America and Africa.

A key promise of globalization was that access to global markets and increased competition would drive an economy’s resources toward more productive uses and enhance allocative efficiency. It is certainly true that firms that are exposed to foreign competition have had no choice but to either become more productive or shut down. As trade barriers have come down, industries have rationalized, upgraded and become more efficient. But an economy’s overall productivity depends not only on what's happening within industries, but also on the reallocation of resources across sectors. This is where globalization has produced a highly uneven result. Our empirical work shows that countries with a comparative advantage in natural resources run the risk of stunting their process of structural transformation. The risks are aggravated by policies that allow the currency to become overvalued and place large costs on firms when they hire or fire workers.

Structural change, like economic growth itself, is not an automatic process. It needs a nudge in the appropriate direction, especially when a country has a strong comparative advantage in natural resources. Globalization does not alter this underlying reality. But it does increase the costs of getting the policies wrong, just as it increases the benefits of getting them right. ${ }^{9}$

\footnotetext{
${ }^{9}$ This is not the place to get into an extended discussion on policies that promote economic diversification. See Cimoli et al. (2009) and Rodrik (2007, chap. 4).
} 


\section{Appendix: Data description}

Our analysis is based on a panel of 38 countries with data on employment, value added (in 2000 PPP U.S. dollars), and labor productivity (also in 2000 PPP U.S. dollars) disaggregated into 9 economic sectors (see Table A.1), starting in 1990 and ending in 2005. Our main source of data is the 10-Sector Productivity Database, by Timmer and de Vries (2009). These data are available at http://www.ggdc.net/databases/10_sector.htm. The latest update available for each country was used. Data for Latin American and Asian countries came from the June 2007 update, while data for the European countries and the U.S. came from the October 2008 update.

We supplemented the 10-Sector Database with data for Turkey, China, and nine African countries: Ethiopia, Ghana, Kenya, Malawi, Mauritius, Nigeria, Senegal, South Africa, and Zambia. In compiling this extended dataset, we followed Timmer and de Vries (2009) as closely as possible so that the resulting value added, employment and labor productivity data would be comparable to that of the 10-Sector Database. Our data includes information on value added, aggregated into 9 main sectors according to the definitions in the $2^{\text {nd }}$ revision of the international standard industrial classification (ISIC, rev. 2), from national accounts data from a variety of national and international sources. Similarly, we used data from several population censuses as well as labor and household surveys to get estimates of sectoral employment. Following Timmer and de Vries (2009), we define sectoral employment as all persons employed in a particular sector, regardless of their formality status or whether they were self-employed or familyworkers. Also following Timmer and de Vries, we use population census data to measure levels of employment by sector and complement this data with labor force surveys (LFS) or comprehensive household surveys to obtain labor force growth rates.

\section{Supplementing the 10-Sector Database}

Data on value added by sector for Turkey comes from national accounts data from the Turkish Statistical Institute (TurkStat). The latest available benchmark year is 1998 and TurkStat publishes sectoral value added figures (in current and constant 1998 prices) with this benchmark year starting in 1998 and going all the way up to 2009. These series were linked with series on sectoral value added (in current and constant prices) with a different benchmark year (i.e. 1987) which yielded sectoral value added series going from 1968 to $2009 .^{10}$ This was done for sectoral value added in current and constant prices. Data on employment by sector comes from sectoral employment estimates published by Turkstat. These estimates come from annual household LFS that are updated with data from the most recent population census. These surveys cover all persons employed regardless of their rural or urban status, formality status, and cover selfemployed and family workers. Hence, they seem to be a good and reliable source of total employment by sector.

Chinese data were compiled from several China Statistical Yearbooks, published by the National Bureau of Statistics (NBS). The Statistical Yearbooks include data on value added (in current and constant prices) disaggregated into three main "industries": primary, secondary and tertiary. The NBS further decomposes the secondary industry series into construction and

\footnotetext{
${ }^{10}$ We linked these series with the ones having 1998 as a benchmark year using yearly sectoral value added growth rates for the 1968-1998 period published by Turkstat.
} 
“industry” (i.e. all other non-construction activities in the secondary sector). The tertiary industry series includes data on services. In order to get disaggregated value added series for the other 7 sectors of interest (i.e. sectors other than agriculture and construction) we had to disaggregate value added data for the secondary and tertiary sectors. We did this by calculating sectoral distributions of value added for the non-construction secondary industry and tertiary industry from different tables published by the NBS. We then used these distributions and the yearly value added series for the non-construction secondary industry and the tertiary industry to get estimates of sectoral value added for the other 7 sectors of interest. These estimates, along with the value added series for the primary industry (i.e. agriculture, hunting, forestry and fishing) and the construction sector, yielded series of value added by sector disaggregated into our 9 sectors of interest.

Sectoral employment was calculated using data from the NBS. The NBS publishes reliable sectoral employment estimates based on data from a number of labor force surveys and calibrated using data from the different population censuses. Given the availability and reliability of these estimates and that they are based on and calibrated using data from the different rounds of population censuses, we decided to use these employment series to get our sectoral employment estimates. In some cases, we aggregated the NBS' employment series to get sectoral employment at the level we wanted. ${ }^{11}$

Our African sample includes Ethiopia, Ghana, Kenya, Malawi, Mauritius, Nigeria, Senegal, South Africa, and Zambia and covers almost half of total sub-Saharan population (47\%) and close to two thirds of total sub-Saharan GDP (63\%). ${ }^{12}$ The particular steps to get estimates of sectoral value added and employment for these sub-Saharan countries varied due to differences in data availability. Once again, we followed Timmer and de Vries' $(2007,2009)$ methodology as closely as possible to ensure comparability with data from the 10-Sector Database. We used data on sectoral employment from population censuses and complemented this with data from labor force surveys and household surveys. We took care to make sure that employment in the informal sector was accounted for. In some cases, this meant using data from surveys of the informal sector (when available) to refine our estimates of sectoral employment. We used data on value added by sector from national accounts data from different national sources and complemented them with data from the UN's national accounts statistics in cases where national sources were incomplete or we found inconsistencies. Due to the relative scarcity of data sources for many of the sub-Saharan economies in our sample, our data are probably not appropriate to study short-term (i.e. yearly) fluctuations, but we think they are still indicative of medium-term trends in sectoral labor productivity.

\footnotetext{
${ }^{11}$ Due to data availability we were only able to calculate estimates of sectoral employment for our 9 sectors of interest from 1990 to 2001. We compared our sectoral employment estimates with those published by the Asian Productivity Organization (APO) in its APO Productivity Database. Our sectoral employment estimates are identical to the ones calculated by the APO for all but the 3 sectors: utilities, wholesale and retail trade, and the community, social, personal and government services sectors. Overall, these discrepancies were small. Moreover, while our sectoral employment estimates only cover the 1990-2001 period, the APO employment estimates go from 1978 to 2007. Given the close match between our estimates and those from the APO, and the longer time period covered by the APO data, we decided to use APO's sectoral employment estimates in order to maintain intertemporal consistency in the sectoral employment data for China.

12 Total GDP (in constant 2000 \$US) and total population in Sub-Saharan Africa in 2009 (WDI, 2010).
} 
Table A.1: Sector coverage

\begin{tabular}{|c|c|c|c|}
\hline Sector & Abbreviation & ISIC rev. 2 & ISIC rev. 3 Equivalent \\
\hline Agriculture, Hunting, Forestry and Fishing & agr & Major division 1 & $A+B$ \\
\hline Mining and Quarrying & $\min$ & Major division 2 & $\mathrm{C}$ \\
\hline Manufacturing & man & Major division 3 & $\mathrm{D}$ \\
\hline Public Utilities (Electricity, Gas, and Water) & $\mathrm{pu}$ & Major division 4 & $\mathrm{E}$ \\
\hline Construction & con & Major division 5 & $\mathrm{~F}$ \\
\hline $\begin{array}{l}\text { Wholesale and Retail Trade, Hotels and } \\
\text { Restaurants }\end{array}$ & wrt & Major division 6 & $\mathrm{G}+\mathrm{H}$ \\
\hline Transport, Storage and Communications & tsc & Major divison 7 & I \\
\hline $\begin{array}{l}\text { Finance, Insurance, Real Estate and Business } \\
\text { Services }\end{array}$ & fire & Major division 8 & $\mathrm{~J}+\mathrm{K}$ \\
\hline $\begin{array}{l}\text { Community, Social, Personal and } \\
\text { Government Services }\end{array}$ & cspsgs & Major division 9 & $\mathrm{O}+\mathrm{P}+\mathrm{Q}+\mathrm{L}+\mathrm{M}+\mathrm{N}$ \\
\hline Economy-wide & sum & & \\
\hline
\end{tabular}

Source: Timmer and de Vries (2007) 


\section{REFERENCES}

Bartelsman, Eric, John Haltiwanger, and Stefano Scarpetta "Cross Country Differences in Productivity: The Role of Allocative Efficiency,” December 2006.

Cavalcanti Ferreira, Pedro, and José Luiz Rossi, "New Evidence from Brazil on Trade Liberalization and Productivity Growth,” International Economic Review, Vol. 44, No. 4, Nov., 2003, pp. 1383-1405.

Ciccone, Antonio, and Elias Papaioannou, "Entry Regulation and Intersectoral Reallocation,” unpublished paper, June 2008.

Cimoli, Mario, Giovanni Dosi, and Joseph E. Stiglitz, eds., Industrial Policy and Development: The Political Economy of Capabilities Accumulation, Oxford University Press, Oxford and New York, 2009.

Esclava, Marcela, Haltiwanger, John, Kugler, Adriana D. and Kugler, Maurice, "Trade Reforms and Market Selection: Evidence from Manufacturing Plants in Colombia,” NBER Working Paper No 14935, 2009.

Fernandes, Ana M., "Trade policy, trade volumes and plant-level productivity in Colombian manufacturing industries," Journal of International Economics, Volume 71, Issue 1, March 2007, Pages 52-71.

Hsieh, Chang-Tai and Peter J. Klenow, "Misallocation and Manufacturing TFP in China and India,” Quarterly Journal of Economics, November 2009.

Kuznets, Simon, “Economic Growth and Income Inequality,” The American Economic Review, Vol. 45, No. 1 (Mar., 1955), pp. 1-28.

McKinsey Global Institute, Turkey: Making the Productivity and Growth Breakthrough, McKinsey and Co., Istanbul, 2003.

McMillan, Margaret, Dani Rodrik and K. Horn Welch, "When Economic Reform Goes Wrong: Cashew in Mozambique,” Brookings Trade Forum 2003, Washington, DC 2004.

Mundlak, Yair, Rita Butzer, and Donald F. Larson, "Heterogeneous technology and panel data: The case of the agricultural production function," Hebrew University, Center for Agricultural Economics Research, Discussion paper 1.08, 2008.

Pages, Carmen ed., The Age of Productivity, Inter-American Development Bank, Washington, D.C., 2010.

Paus, Eva, Nola Reinhardt, and Michael Dale Robinson, "Trade Liberalization and Productivity Growth in Latin American Manufacturing, 1970-98,” Journal of Policy Reform, 2003, vol. 6, issue 1 , pages 1-15. 
Pavcnik, Nina, “Trade Liberalization, Exit, and Productivity Improvements: Evidence from Chilean Plants,” NBER Working Paper No. 7852, August 2000.

Rodrik, Dani, One Economics, Many Recipes, Princeton University Press, Princeton, N.J., 2007.

Rodrik, Dani, “The Real Exchange Rate and Economic Growth,” Brookings Papers on Economic Activity, 2008:2.

Thurlow, James, and Peter Wobst, “The Road to Pro-Poor Growth in Zambia: Past Lessons and Future Challenges,” Proceedings of the German Development Economics Conference, Kiel, No. 37, Verein für Socialpolitik, Research Committee Development Economics, 2005.

Timmer, Marcel P., and Gaaitzen J. de Vries, “A Cross-Country Database For Sectoral Employment And Productivity In Asia And Latin America, 1950-2005,” Groningen Growth and Development Centre Research Memorandum GD-98, Groningen: University of Groningen, August 2007.

Timmer, Marcel P., and Gaaitzen J. de Vries, "Structural Change and Growth Accelerations in Asia and Latin America: A New Sectoral Data Set,” Cliometrica, vol 3 (issue 2), 2009, pp. 165190. 
Table 1. Summary Statistics

\begin{tabular}{|c|c|c|c|c|c|c|c|c|c|}
\hline & \multirow[t]{2}{*}{ Country } & \multirow[t]{2}{*}{ Code } & \multirow[t]{2}{*}{$\begin{array}{l}\text { Economy-wide Labor } \\
\text { Productivity* }\end{array}$} & \multirow[t]{2}{*}{$\begin{array}{l}\text { Coef. of Variation of log } \\
\text { of Sectoral Productivity }\end{array}$} & \multicolumn{2}{|c|}{$\begin{array}{l}\text { Sector with Highest } \\
\text { Labor Productivity }\end{array}$} & \multicolumn{2}{|c|}{$\begin{array}{l}\text { Sector with Lowest } \\
\text { Labor Productivity }\end{array}$} & \multirow{2}{*}{$\begin{array}{c}\text { Compound Annual } \\
\text { Growth Rate of Econ. } \\
\text { wide Productivity }\end{array}$} \\
\hline & & & & & Sector & $\begin{array}{c}\text { Labor } \\
\text { Productivity* } \\
\end{array}$ & Sector & $\begin{array}{c}\text { Labor } \\
\text { Productivity* }\end{array}$ & \\
\hline \multicolumn{10}{|c|}{ High Income } \\
\hline 1 & United States & USA & 70,235 & 0.062 & $\mathrm{pu}$ & 391,875 & con & 39,081 & $1.80 \%$ \\
\hline 2 & France & FRA & 56,563 & 0.047 & pu & 190,785 & cspsgs & 37,148 & $1.20 \%$ \\
\hline 3 & Netherlands & NLD & 51,516 & 0.094 & $\min$ & 930,958 & cspsgs & 33,190 & $1.04 \%$ \\
\hline 4 & Italy & ITA & 51,457 & 0.058 & $\mathrm{pu}$ & 212,286 & cspsgs & 36,359 & $0.73 \%$ \\
\hline 5 & Sweden & SWE & 50,678 & 0.051 & $\mathrm{pu}$ & 171,437 & cspsgs & 24,873 & $2.79 \%$ \\
\hline 6 & Japan & $\mathrm{JPN}$ & 48,954 & 0.064 & pu & 173,304 & agr & 13,758 & $1.41 \%$ \\
\hline 7 & United Kingdon & UKM & 47,349 & 0.076 & $\min$ & 287,454 & wrt & 30,268 & $1.96 \%$ \\
\hline 8 & Spain & ESP & 46,525 & 0.062 & $\mathrm{pu}$ & 288,160 & con & 33,872 & $0.64 \%$ \\
\hline 9 & Denmark & DNK & 45,423 & 0.088 & $\min$ & 622,759 & cspsgs & 31,512 & $1.53 \%$ \\
\hline \multicolumn{10}{|l|}{ Asia } \\
\hline 10 & Hong Kong & HKG & 66,020 & 0.087 & pu & 407,628 & agr & 14,861 & $3.27 \%$ \\
\hline 11 & Singapore & SGP & 62,967 & 0.068 & $\mathrm{pu}$ & 192,755 & agr & 18,324 & $3.71 \%$ \\
\hline 12 & Taiwan & TWN & 46,129 & 0.094 & $\mathrm{pu}$ & 283,639 & agr & 12,440 & $3.99 \%$ \\
\hline 13 & South Korea & KOR & 33,552 & 0.106 & $\mathrm{pu}$ & 345,055 & fire & 9,301 & $3.90 \%$ \\
\hline 14 & Malaysia & MYS & 32,712 & 0.113 & $\min$ & 469,892 & con & 9,581 & $4.08 \%$ \\
\hline 15 & Thailand & THA & 13,842 & 0.127 & $\mathrm{pu}$ & 161,943 & agr & 3,754 & $3.05 \%$ \\
\hline 16 & Indonesia & IDN & 11,222 & 0.106 & $\min$ & 85,836 & agr & 4,307 & $2.78 \%$ \\
\hline 17 & Philippines & PHL & 10,146 & 0.097 & $\mathrm{pu}$ & 90,225 & agr & 5,498 & $0.95 \%$ \\
\hline 18 & China & $\mathrm{CHN}$ & 9,518 & 0.122 & fire & 105,832 & agr & 2,594 & $8.78 \%$ \\
\hline 19 & India & IND & 7,700 & 0.087 & $\mathrm{pu}$ & 47,572 & agr & 2,510 & $4.23 \%$ \\
\hline \multicolumn{10}{|c|}{ Middle East } \\
\hline 20 & Turkey & TUR & 25,957 & 0.080 & $\mathrm{pu}$ & 148,179 & agr & 11,629 & $3.16 \%$ \\
\hline \multicolumn{10}{|c|}{ Latin America } \\
\hline 21 & Argentina & ARG & 30,340 & 0.083 & $\min$ & 239,645 & fire & 18,290 & $2.35 \%$ \\
\hline 22 & Chile & $\mathrm{CHL}$ & 29,435 & 0.084 & $\min$ & 194,745 & wrt & 17,357 & $2.93 \%$ \\
\hline 23 & Mexico & MEX & 23,594 & 0.078 & $\mathrm{pu}$ & 88,706 & agr & 9,002 & $1.07 \%$ \\
\hline 24 & Venezuela & VEN & 20,799 & 0.126 & $\min$ & 297,975 & $\mathrm{pu}$ & 7,392 & $-0.35 \%$ \\
\hline 25 & Costa Rica & CRI & 20,765 & 0.056 & tsc & 55,744 & $\min$ & 10,575 & $1.25 \%$ \\
\hline 26 & Colombia & $\mathrm{COL}$ & 14,488 & 0.108 & pu & 271,582 & wrt & 7,000 & $0.18 \%$ \\
\hline 27 & Peru & PER & 13,568 & 0.101 & pu & 117,391 & agr & 4,052 & $3.41 \%$ \\
\hline 28 & Brazil & BRA & 12,473 & 0.111 & pu & 111,923 & wrt & 4,098 & $0.44 \%$ \\
\hline 29 & Bolivia & $\mathrm{BOL}$ & 6,670 & 0.137 & $\min$ & 121,265 & con & 2,165 & $0.88 \%$ \\
\hline \multicolumn{10}{|l|}{ Africa } \\
\hline 30 & South Africa & ZAF & 35,760 & 0.074 & pu & 91,210 & con & 10,558 & $0.63 \%$ \\
\hline 31 & Mauritius & MUS & 35,381 & 0.058 & $\mathrm{pu}$ & 137,203 & agr & 24,795 & $3.44 \%$ \\
\hline 32 & Nigeria & NGA & 4,926 & 0.224 & $\min$ & 866,646 & cspsgs & 264 & $2.28 \%$ \\
\hline 33 & Senegal & SEN & 4,402 & 0.178 & fire & 297,533 & agr & 1,271 & $0.47 \%$ \\
\hline 34 & Kenya & KEN & 3,707 & 0.158 & $\mathrm{pu}$ & 73,937 & wrt & 1,601 & $-1.22 \%$ \\
\hline 35 & Ghana & GHA & 3,280 & 0.132 & $\mathrm{pu}$ & 47,302 & wrt & 1,507 & $1.05 \%$ \\
\hline 36 & Zambia & $\mathrm{ZMB}$ & 2,643 & 0.142 & fire & 47,727 & agr & 575 & $-0.32 \%$ \\
\hline 37 & Ethiopia & ETH & 2,287 & 0.154 & fire & 76,016 & agr & 1,329 & $1.87 \%$ \\
\hline 38 & Malawi & MWI & 1,354 & 0.176 & $\min$ & 70,846 & agr & 521 & $-0.47 \%$ \\
\hline
\end{tabular}

Note: All numbers are for 2005 unless otherwise stated

* 2000 PPP SUS. All numbers are for 2005 unless otherwise stated. 


\section{Table 2. Sector Coverage}

\begin{tabular}{|c|c|c|c|c|c|c|}
\hline \multirow[t]{2}{*}{ Sector } & \multirow[t]{2}{*}{ Abbreviation } & \multirow[t]{2}{*}{$\begin{array}{l}\text { Average Sectoral Labor } \\
\text { Productivity* }\end{array}$} & \multicolumn{2}{|c|}{$\begin{array}{l}\text { Maximun Sectoral Labor } \\
\text { Productivity }\end{array}$} & \multicolumn{2}{|c|}{$\begin{array}{l}\text { Minimum Sectoral Labor } \\
\text { Productivity }\end{array}$} \\
\hline & & & Country & Labor Productivity* & Country & Labor Productivity* \\
\hline Agriculture, Hunting, Forestry and Fishing & agr & 17,530 & USA & 65,306 & MWI & 521 \\
\hline Mining and Quarrying & $\min$ & 154,648 & NLD & 930,958 & ETH & 3,652 \\
\hline Manufacturing & man & 38,503 & USA & 114,566 & ETH & 2,401 \\
\hline Public Utilities (Electricity, Gas, and Water) & $\mathrm{pu}$ & 146,218 & HKG & 407,628 & MWI & 6,345 \\
\hline Construction & con & 24,462 & VEN & 154,672 & MWI & 2,124 \\
\hline Wholesale and Retail Trade, Hotels and Restaurants & wrt & 22,635 & HKG & 60,868 & GHA & 1,507 \\
\hline Transport, Storage and Communications & tsc & 46,421 & USA & 101,302 & GHA & 6,671 \\
\hline Finance, Insurance, Real Estate and Business Services & fire & 62,184 & SEN & 297,533 & KOR & 9,301 \\
\hline $\begin{array}{l}\text { Community, Social, Personal and Government } \\
\text { Services }\end{array}$ & cspsgs & 20,534 & TWN & 53,355 & NGA & 264 \\
\hline Economy-wide & sum & 27,746 & USA & 70,235 & MWI & 1,354 \\
\hline
\end{tabular}

Note: All numbers are for 2005 unless otherwise stated

* 2000 PPP \$US. All numbers are for 2005 unless otherwise stated 
Table 3: Decomposition of productivity growth, unweighted averages, 1990-2005

\begin{tabular}{lcccc}
\hline \hline & $\begin{array}{c}\text { labor productivity } \\
\text { growth }\end{array}$ & & \multicolumn{2}{c}{ component due to: } \\
\cline { 2 - 2 } \cline { 5 - 5 } LAC & $1.35 \%$ & & $2.24 \%$ & "within" \\
AFRICA & $0.86 \%$ & & $2.13 \%$ & $-0.88 \%$ \\
ASIA & $3.87 \%$ & & $3.31 \%$ & $-1.27 \%$ \\
HI & $1.46 \%$ & & $1.54 \%$ & $0.57 \%$ \\
\hline
\end{tabular}


Table 4: Country rankings

\begin{tabular}{|c|c|c|c|c|c|c|c|}
\hline \multicolumn{4}{|c|}{ ranked by the contribution of "within" } & \multicolumn{4}{|c|}{ ranked by the contribution of "str. change" } \\
\hline rank & country & region & "within" & rank & country & region & $\begin{array}{l}\text { "structural } \\
\text { change" }\end{array}$ \\
\hline 1 & $\mathrm{CHN}$ & ASIA & $7.79 \%$ & 1 & THA & ASIA & $1.67 \%$ \\
\hline 2 & ZMB & AFRICA & $7.61 \%$ & 2 & ETH & AFRICA & $1.48 \%$ \\
\hline 3 & KOR & ASIA & $5.29 \%$ & 3 & TUR & TURKEY & $1.42 \%$ \\
\hline 4 & NGA & AFRICA & $4.08 \%$ & 4 & HKG & ASIA & $1.25 \%$ \\
\hline 5 & PER & LAC & $3.85 \%$ & 5 & IDN & ASIA & $1.06 \%$ \\
\hline 6 & $\mathrm{CHL}$ & LAC & $3.82 \%$ & 6 & $\mathrm{CHN}$ & ASIA & $0.99 \%$ \\
\hline 7 & SGP & ASIA & $3.79 \%$ & 7 & IND & ASIA & $0.99 \%$ \\
\hline 8 & SEN & AFRICA & $3.61 \%$ & 8 & GHA & AFRICA & $0.59 \%$ \\
\hline 9 & MYS & ASIA & $3.59 \%$ & 9 & TWN & ASIA & $0.54 \%$ \\
\hline 10 & TWN & ASIA & $3.45 \%$ & 10 & MYS & ASIA & $0.49 \%$ \\
\hline 11 & BOL & LAC & $3.37 \%$ & 11 & MUS & AFRICA & $0.38 \%$ \\
\hline 12 & IND & ASIA & $3.24 \%$ & 12 & CRI & LAC & $0.38 \%$ \\
\hline 13 & VEN & LAC & $3.20 \%$ & 13 & MEX & LAC & $0.23 \%$ \\
\hline 14 & MUS & AFRICA & $3.06 \%$ & 14 & KEN & AFRICA & $0.23 \%$ \\
\hline 15 & ARG & LAC & $2.94 \%$ & 15 & ITA & $\mathrm{HI}$ & $0.17 \%$ \\
\hline 16 & SWE & $\mathrm{HI}$ & $2.83 \%$ & 16 & $\mathrm{PHL}$ & ASIA & $0.14 \%$ \\
\hline 17 & UKM & $\mathrm{HI}$ & $2.47 \%$ & 17 & ESP & $\mathrm{HI}$ & $0.13 \%$ \\
\hline 18 & USA & $\mathrm{HI}$ & $2.09 \%$ & 18 & DNK & $\mathrm{HI}$ & $0.02 \%$ \\
\hline 19 & HKG & ASIA & $2.02 \%$ & 19 & FRA & $\mathrm{HI}$ & $0.00 \%$ \\
\hline 20 & TUR & TURKEY & $1.74 \%$ & 20 & JPN & $\mathrm{HI}$ & $-0.01 \%$ \\
\hline
\end{tabular}


Table 5: Determinants of the magnitude of the structural-change term

\begin{tabular}{|c|c|c|c|c|c|}
\hline \multicolumn{6}{|c|}{ Dependent variable: structural-change term } \\
\hline & $(1)$ & (2) & (3) & (4) & (5) \\
\hline \multirow[t]{2}{*}{ agricultural share in employment } & 0.013 & 0.027 & 0.016 & 0.023 & \\
\hline & $(0.98)$ & $(2.26)^{* *}$ & $(1.48)$ & $(2.45)^{* *}$ & \\
\hline \multirow[t]{2}{*}{ raw materials share in exports } & & -0.050 & -0.045 & -0.046 & -0.038 \\
\hline & & $(2.44)^{* *}$ & $(2.41)^{* *}$ & $(2.73)^{* *}$ & $(2.29)^{* *}$ \\
\hline \multirow[t]{2}{*}{ undervaluation index } & & & 0.016 & 0.017 & 0.023 \\
\hline & & & $(1.75)^{* * *}$ & $(1.80)^{* * *}$ & $(2.24)^{* *}$ \\
\hline \multirow[t]{2}{*}{ employment rigidity index $(0-1)$} & & & & -0.026 & -0.021 \\
\hline & & & & $(2.64)^{* *}$ & $(2.15)^{* *}$ \\
\hline \multirow[t]{2}{*}{ Latin America dummy } & -0.014 & 0.007 & 0.006 & 0.013 & 0.007 \\
\hline & $(2.65)^{* *}$ & $(0.74)$ & $(0.72)$ & (1.49) & $(0.85)$ \\
\hline \multirow[t]{2}{*}{ Africa dummy } & -0.022 & -0.006 & -0.005 & -0.004 & -0.003 \\
\hline & $(2.04)^{* *}$ & $(0.80)$ & $(0.83)$ & $(0.75)$ & $(0.38)$ \\
\hline \multirow[t]{2}{*}{ High income dummy } & -0.003 & -0.001 & 0.008 & 0.013 & 0.010 \\
\hline & $(0.66)$ & $(0.14)$ & (0.98) & (1.47) & $(1.06)$ \\
\hline \multirow[t]{2}{*}{ constant } & 0.002 & 0.005 & 0.006 & 0.009 & 0.014 \\
\hline & $(0.30)$ & (1.11) & (1.37) & (2.03) & $(3.63)^{*}$ \\
\hline Observations & 38 & 38 & 38 & 37 & 37 \\
\hline R-squared & 0.22 & 0.43 & 0.48 & 0.55 & 0.50 \\
\hline
\end{tabular}

Robust t-statistics in parentheses

${ }^{*}$ significant at $1 \%$ level; ${ }^{* *}$ significant at $5 \%$ level; *** significant at $10 \%$ level 


\section{Labor Productivity Gaps in Turkey, 2008}

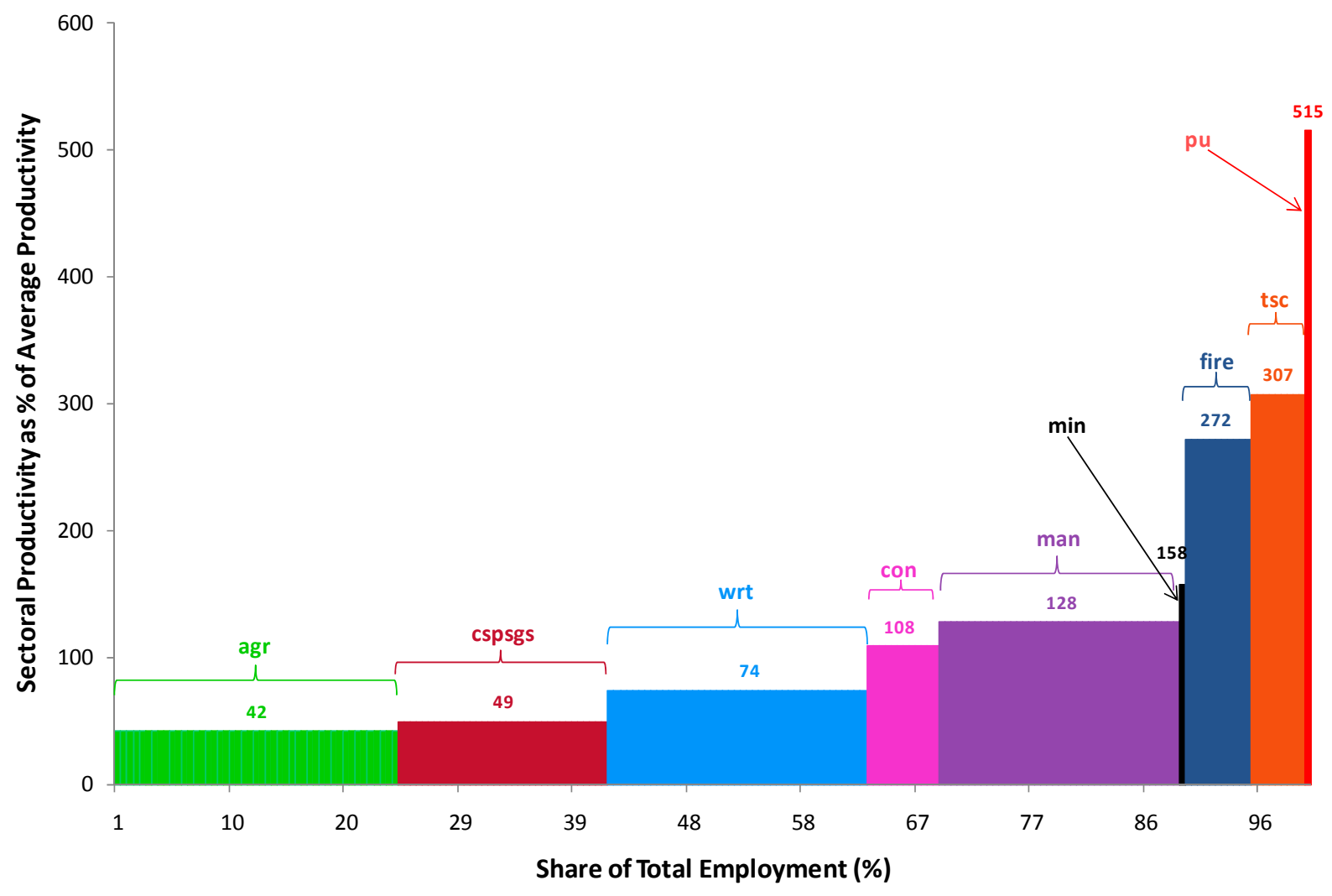

Figure 1: Labor productivity gaps in Turkey

Note: Unless otherwise noted, the source for all the data is the dataset described in the main body of the paper. Abbreviations are as follows: (agr) Agriculture; (min) Mining; (mfg) Manufacturing; (pu) Public Utilities; (con) Construction; (wrt) Retail and Wholesale Trade; (tsc) Transport and Communication; (fire) Finance and Business Services; (cspsgs) Community, Social, Personal and Government Services. 


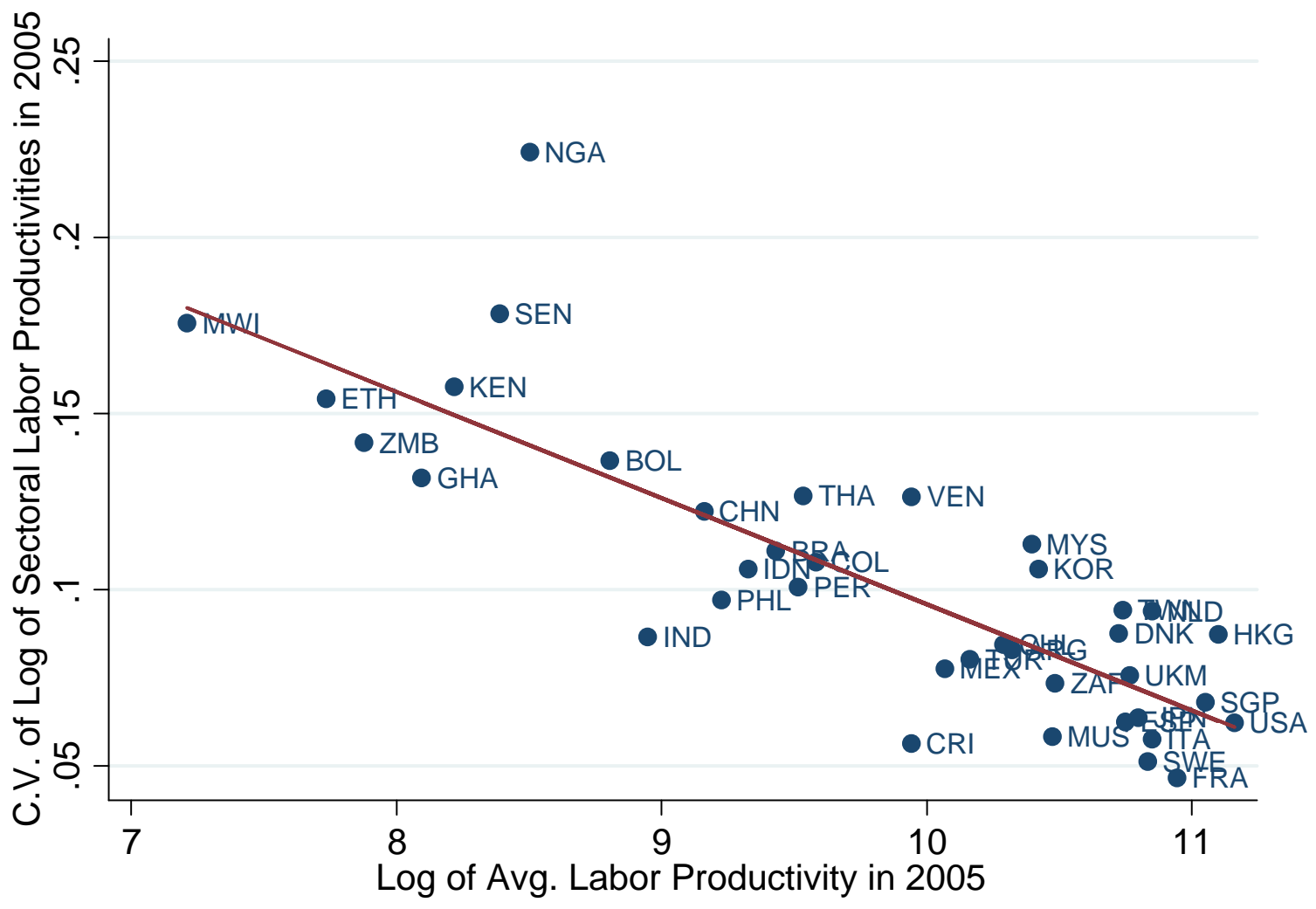

Figure 2: Relationship between inter-sectoral productivity gaps and income levels.

The coefficient of variation in sectoral labor productivities within countries (vertical axis) is graphed against the log of the countries' average labor productivity (horizontal axis), both in 2005 


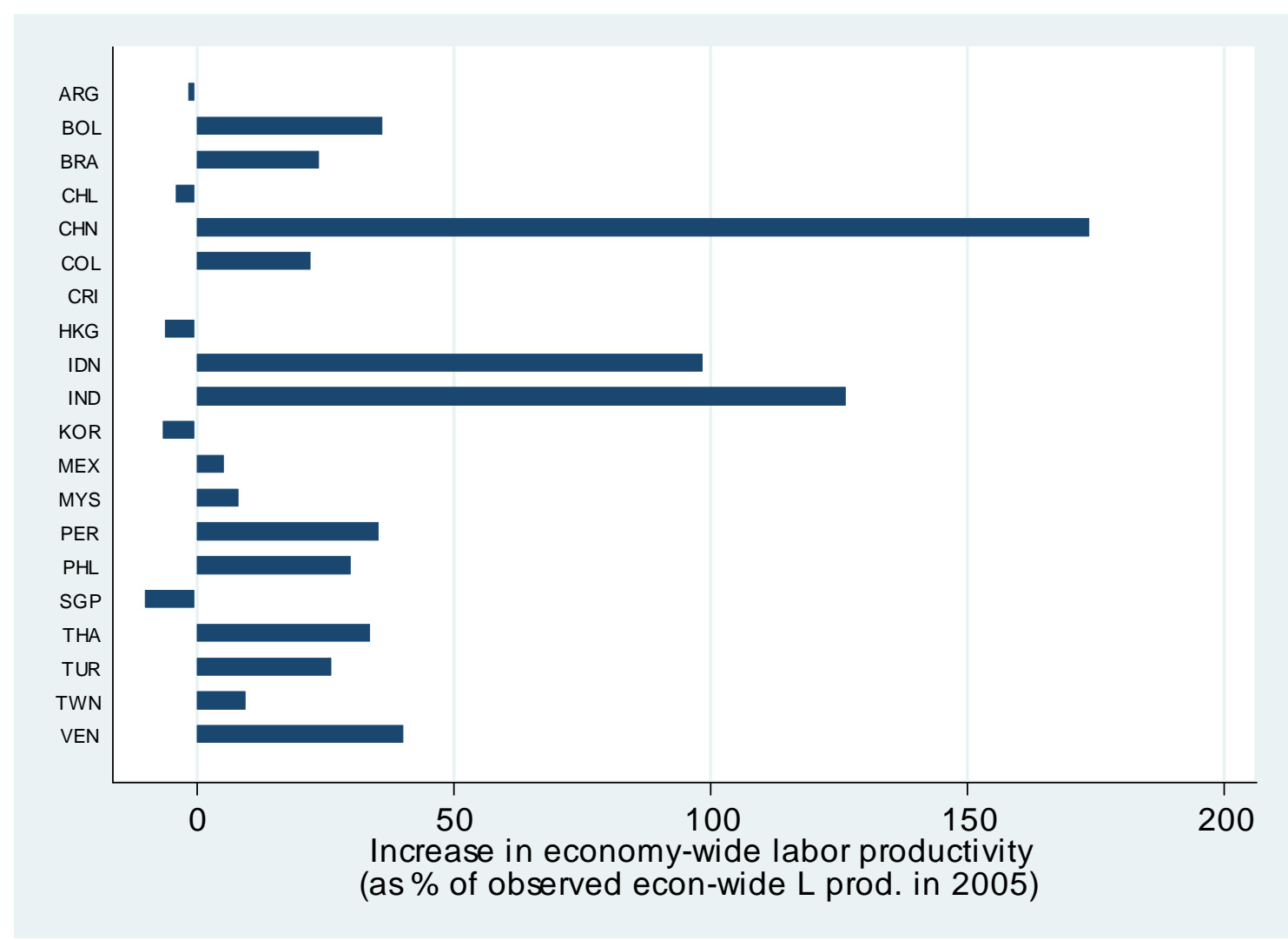

Figure 3: Counterfactual impact of changed economic structure on economy-wide labor productivity, non-African countries

These figures are the percent increase in economy-wide average labor productivity obtained under the assumption that the inter-sectoral composition of the labor force matches the pattern observed in the rich countries. 


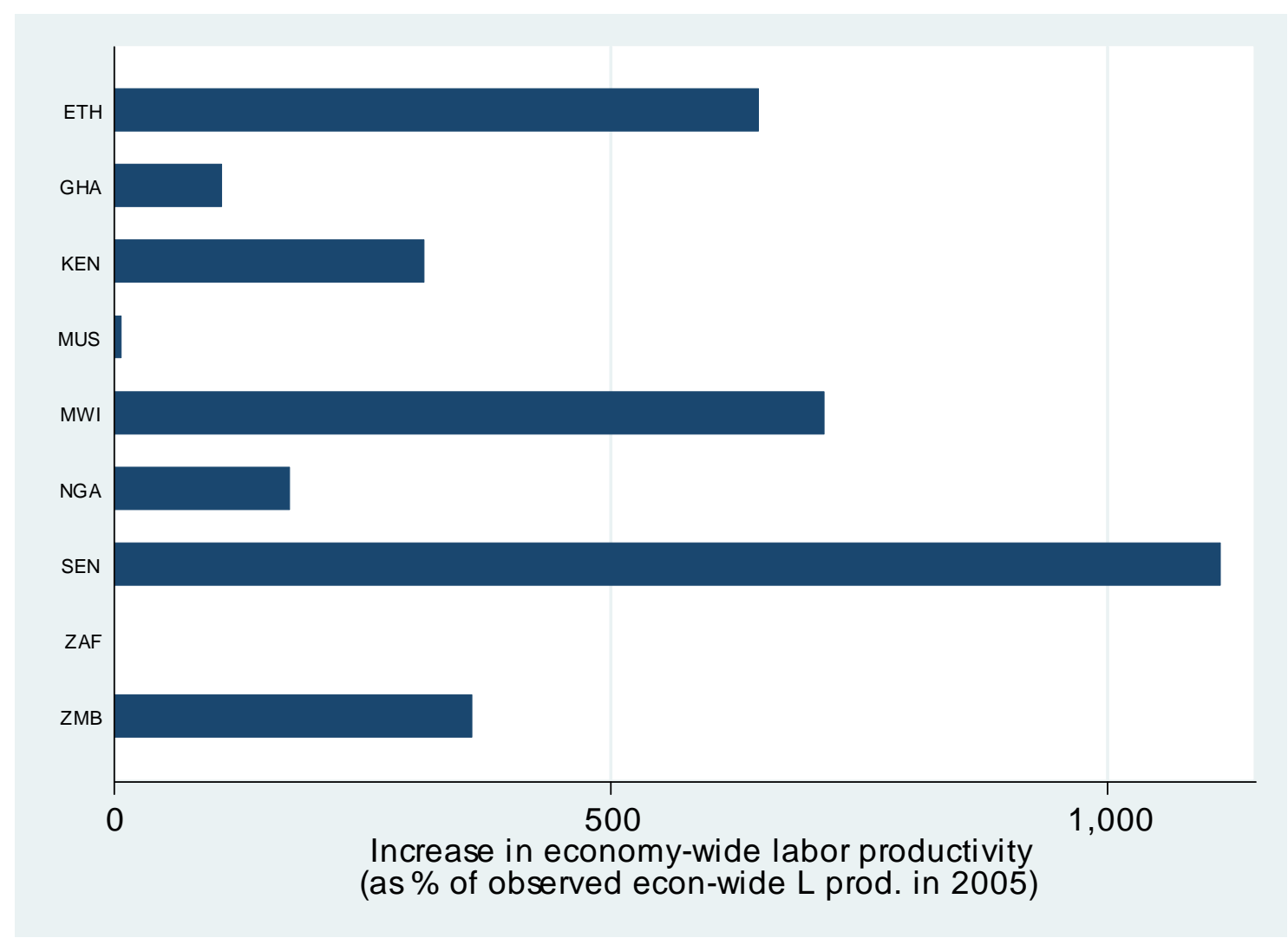

Figure 4: Counterfactual impact of changed economic structure on economy-wide labor productivity, African countries

These figures are the percent increase in economy-wide average labor productivity obtained under the assumption that the inter-sectoral composition of the labor force matches the pattern observed in the rich countries. 


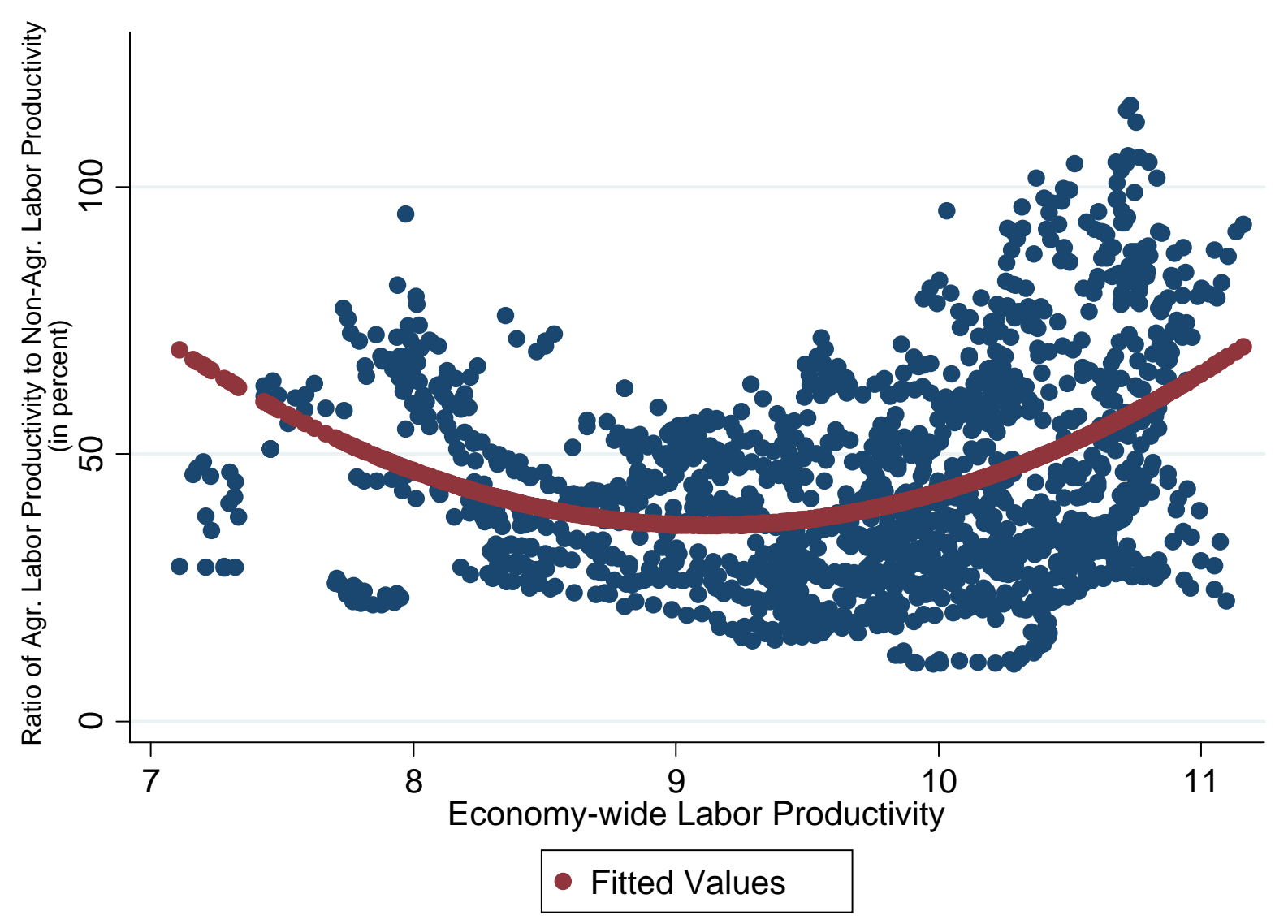

Figure 5: Relationship between economy-wide labor productivity (horizontal axis) and the ratio of agricultural productivity to non-agricultural productivity (percent, vertical axis), full panel. 


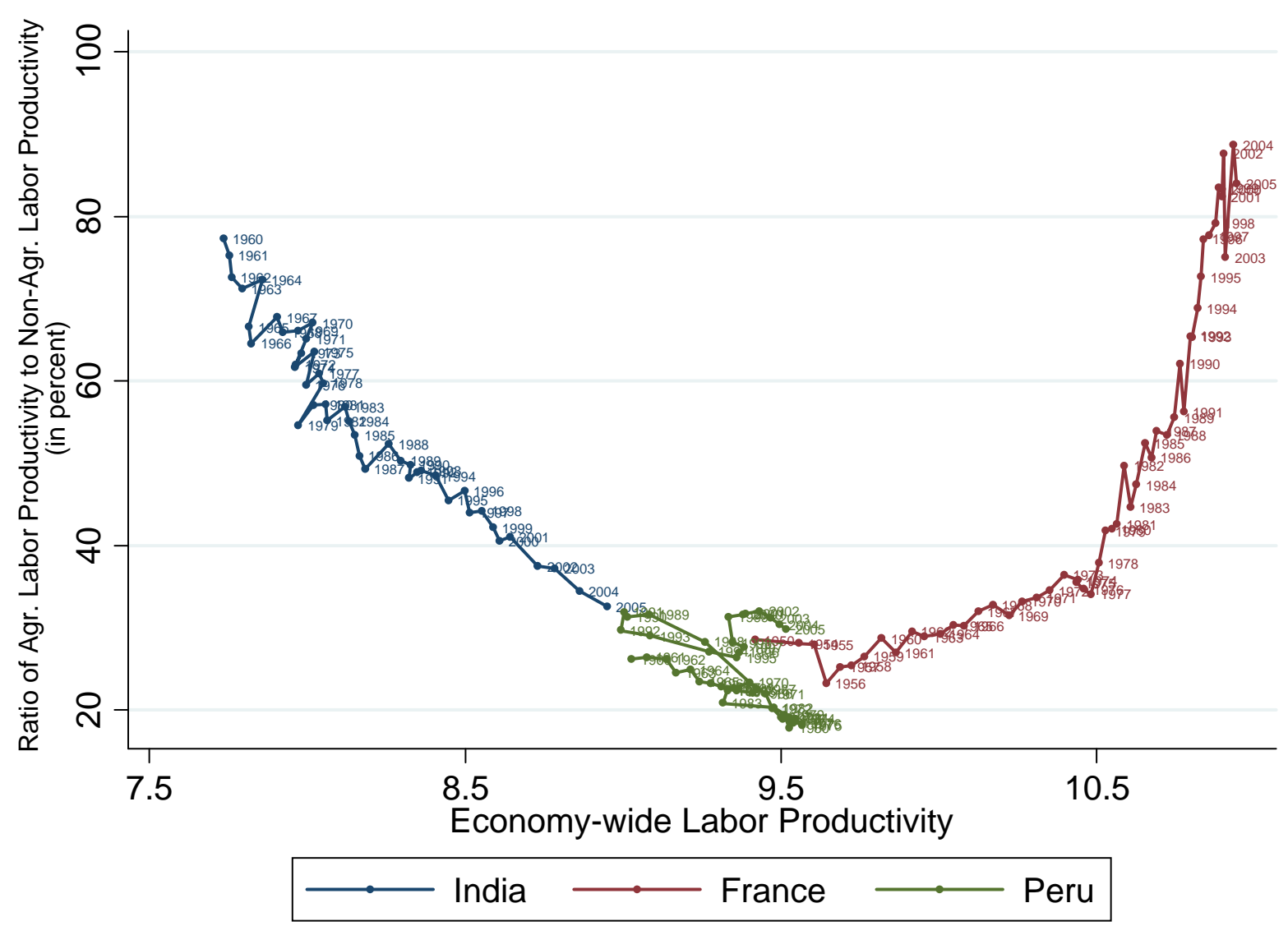

Figure 6: Relationship between economy-wide labor productivity (horizontal axis) and the ratio of agricultural productivity to non-agricultural productivity (percent, vertical axis), selected countries 
Productivity decomposition in Latin America across different periods (annual growth rates)

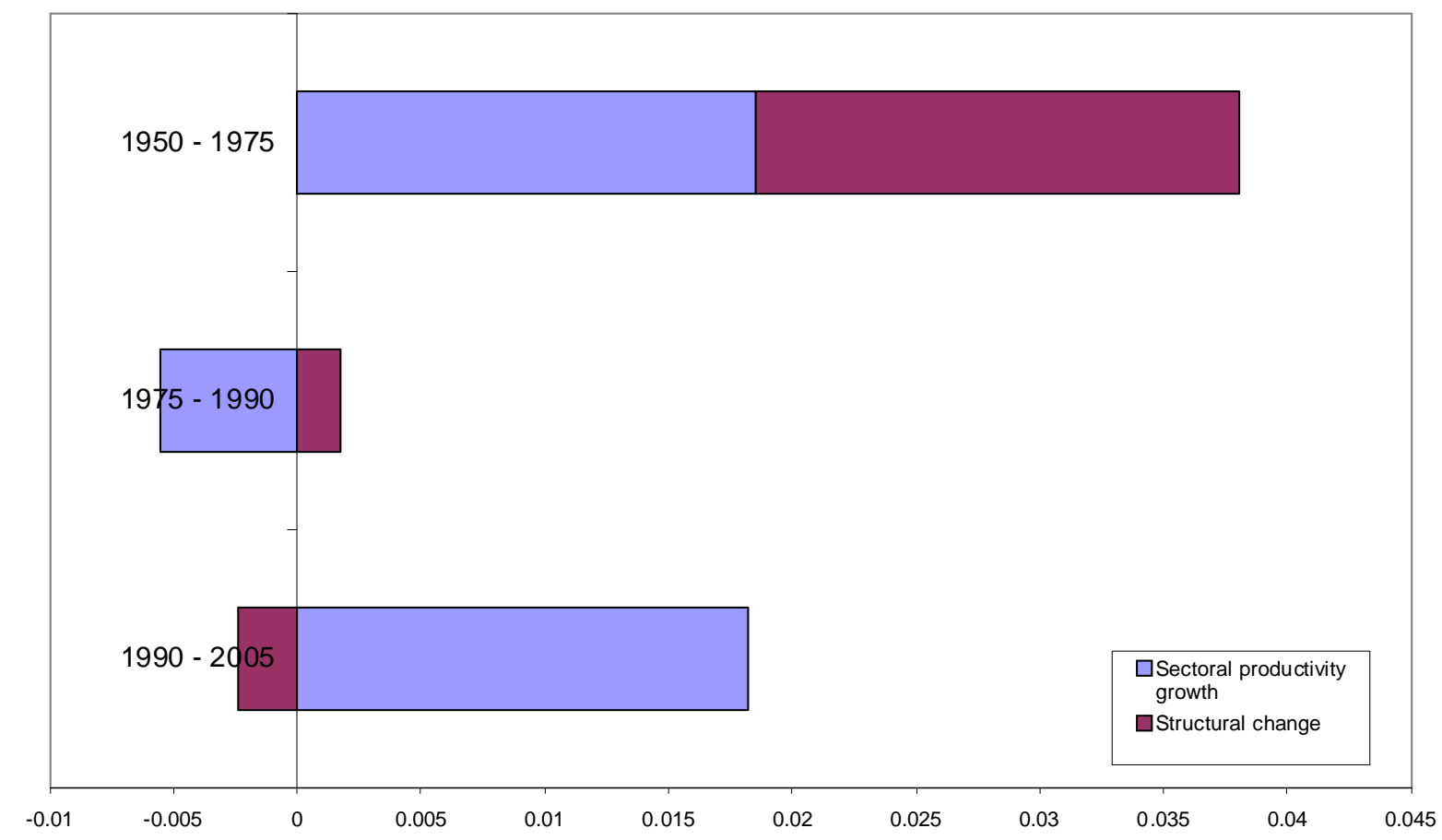

Figure 7: Productivity decomposition for Latin America, 1950-2005

Source: Pages et al., 2010. 


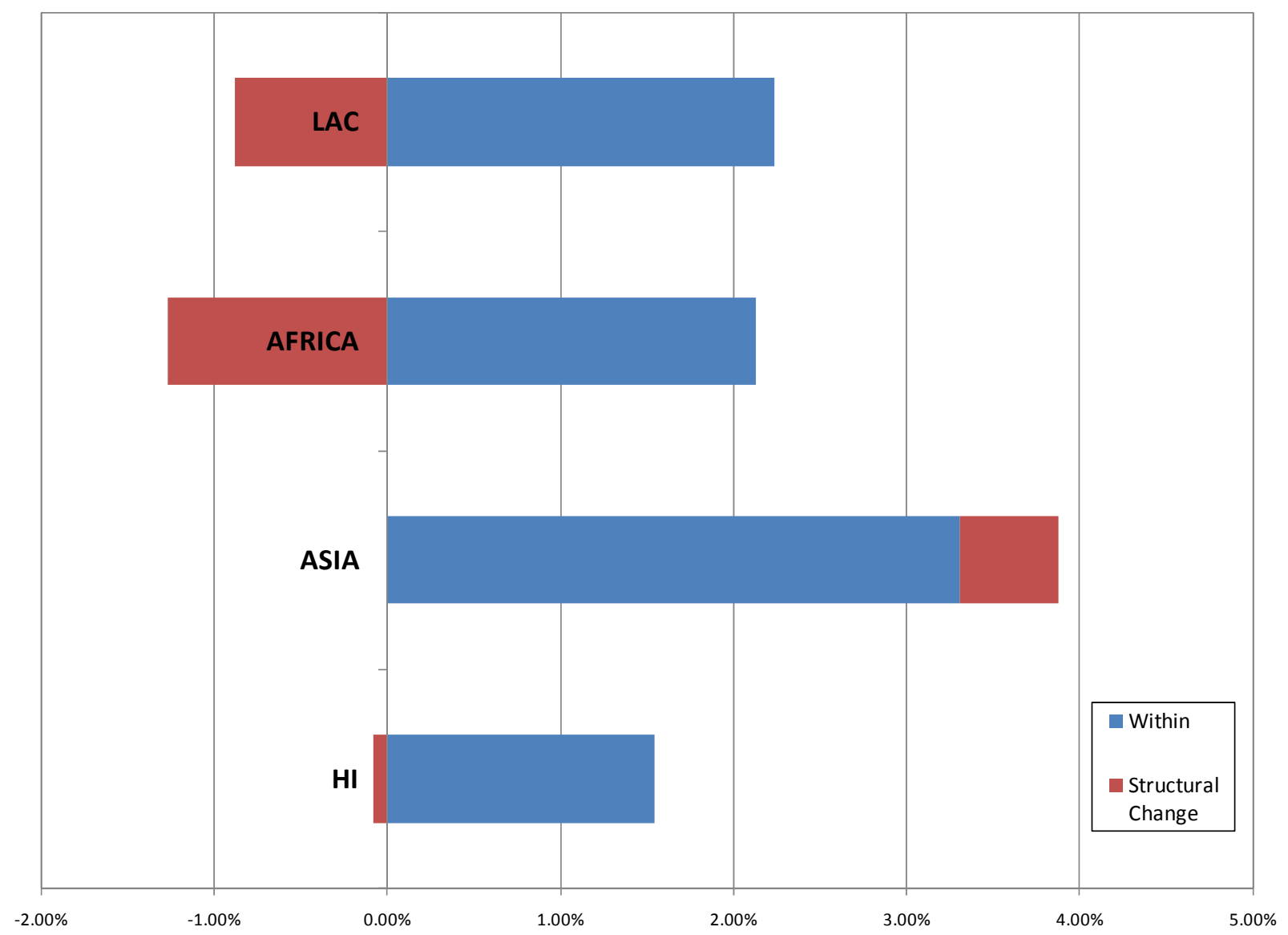

Figure 8: Decomposition of productivity growth by country group, 1990-2005 


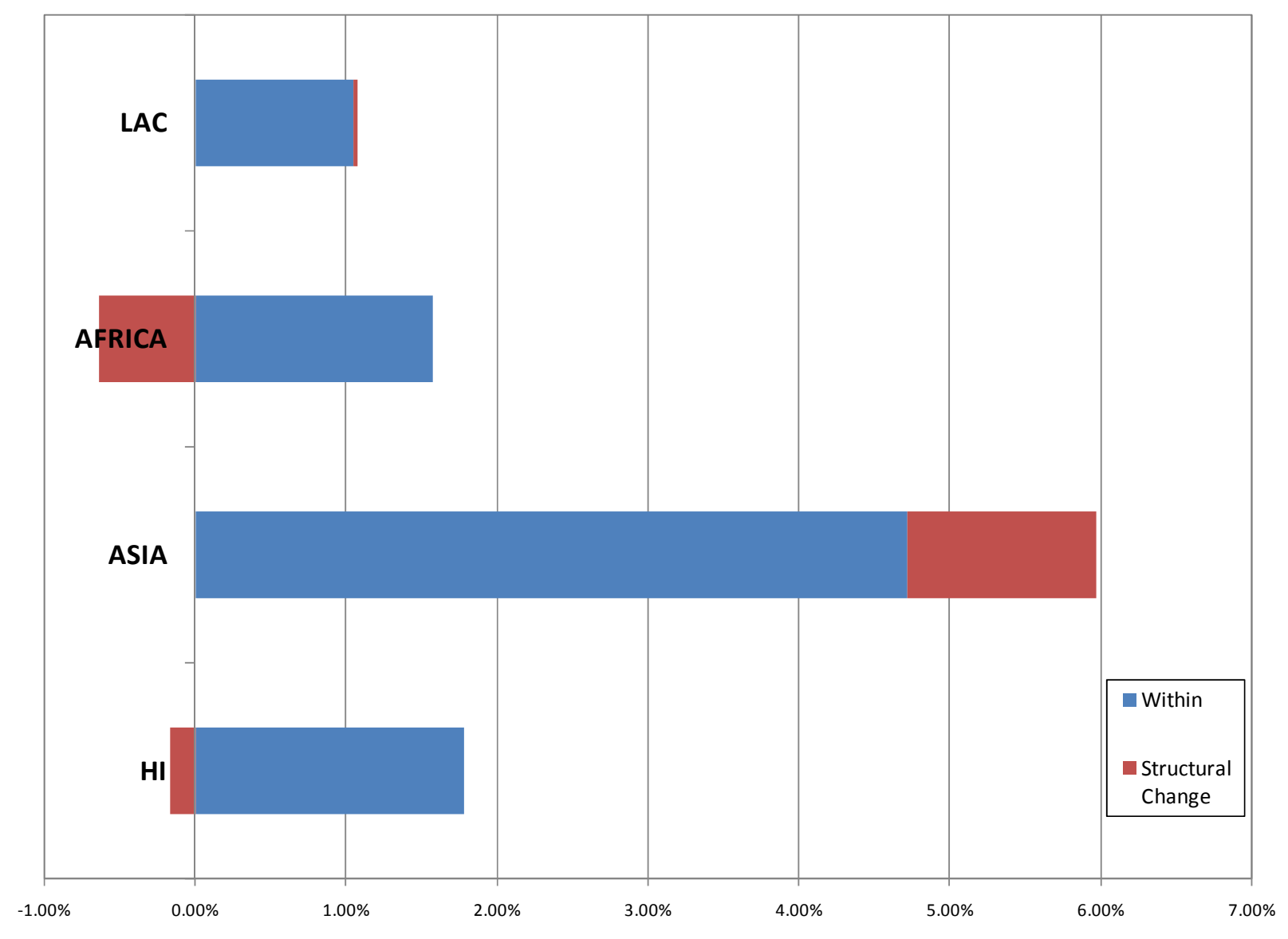

Figure 9: Decomposition of productivity growth by country group, 1990-2005 (weighted averages) 


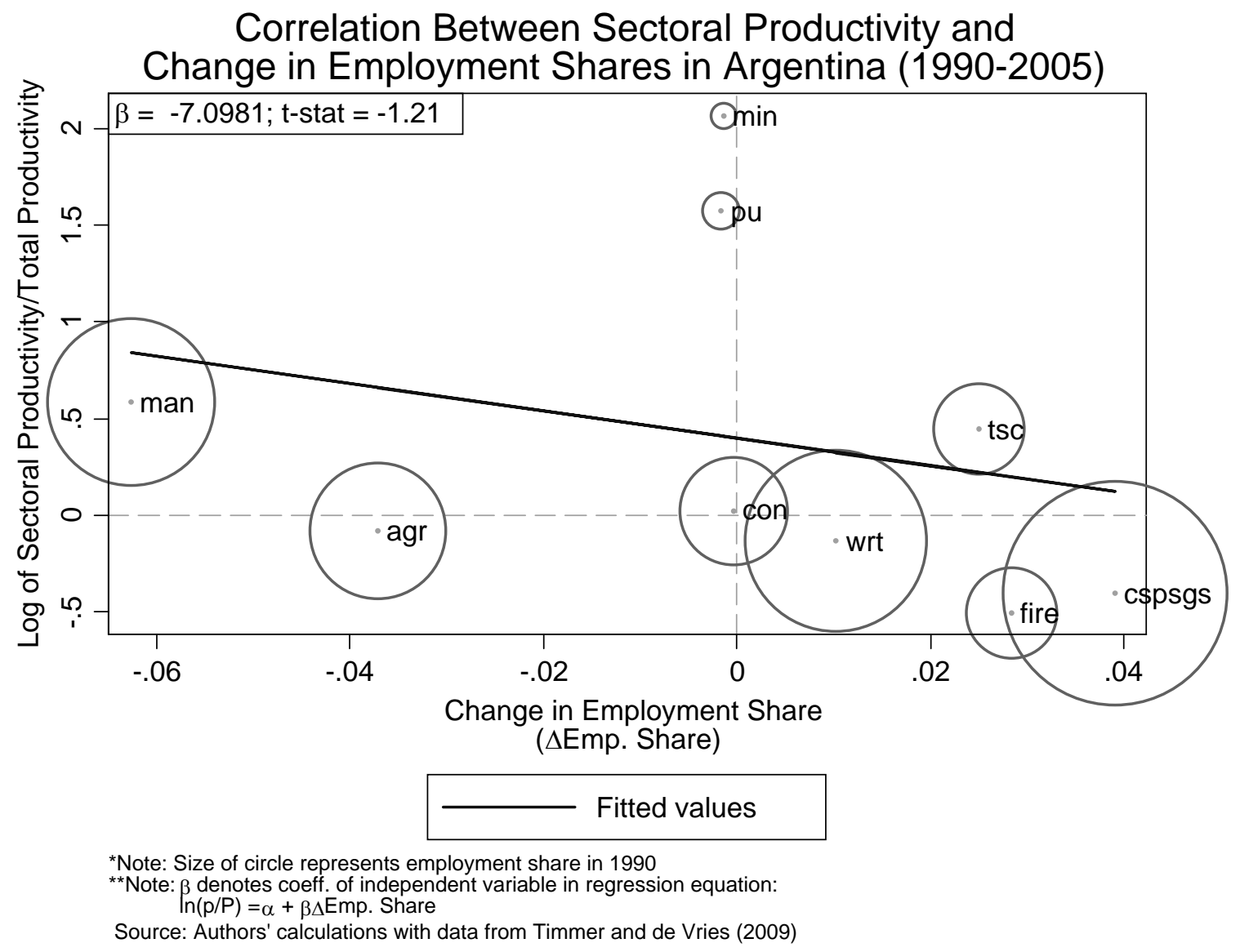

Figure 10

Note: Abbreviations are as follows: (agr) Agriculture; (min) Mining; (mfg) Manufacturing; (pu) Public Utilities; (con) Construction; (wrt) Retail and Wholesale Trade; (tsc) Transport and Communication; (fire) Finance and Business Services; (cspsgs) Community, Social, Personal and Government Services. 


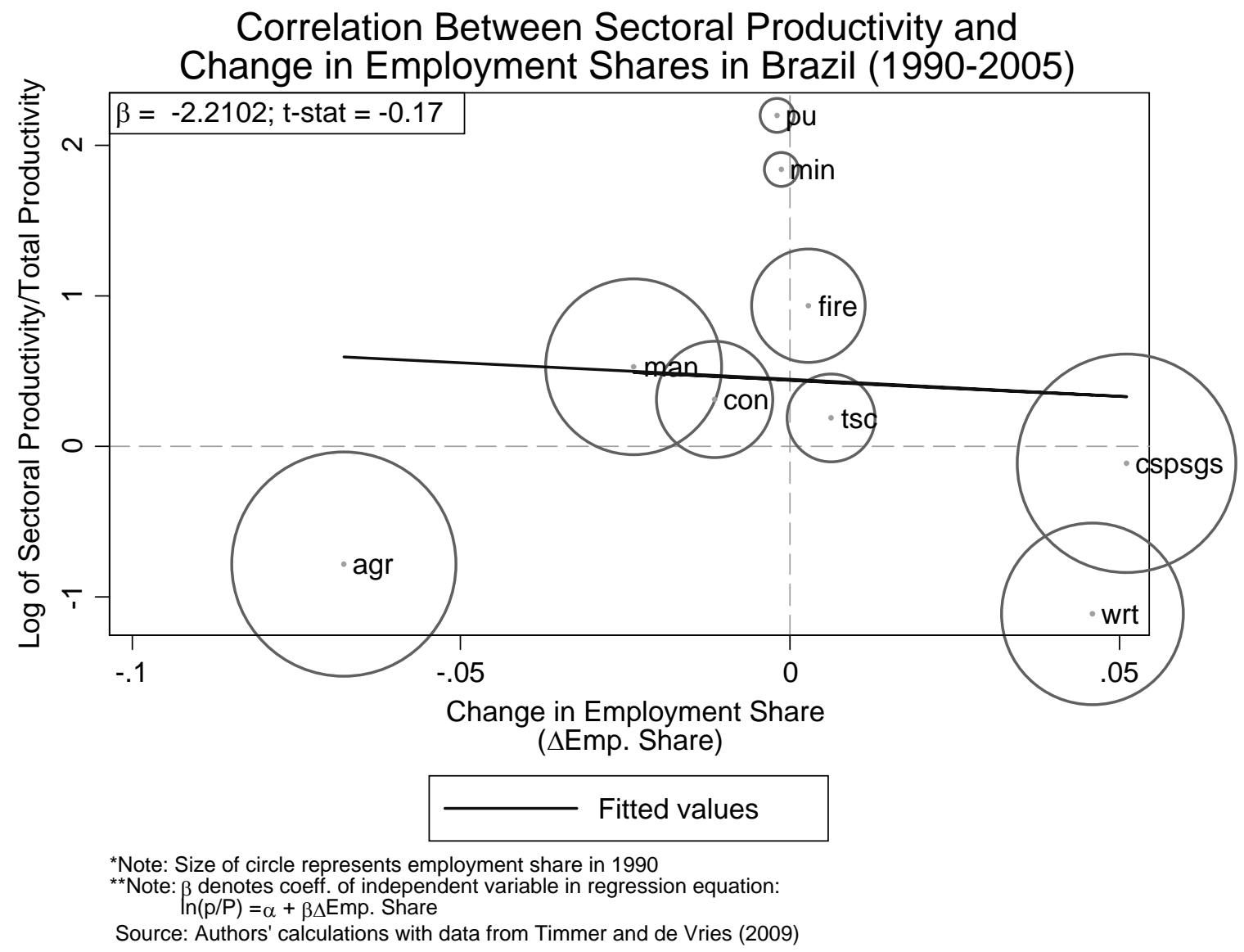

Figure 11

Note: Abbreviations are as follows: (agr) Agriculture; (min) Mining; (mfg) Manufacturing; (pu) Public Utilities; (con) Construction; (wrt) Retail and Wholesale Trade; (tsc) Transport and Communication; (fire) Finance and Business Services; (cspsgs) Community, Social, Personal and Government Services. 


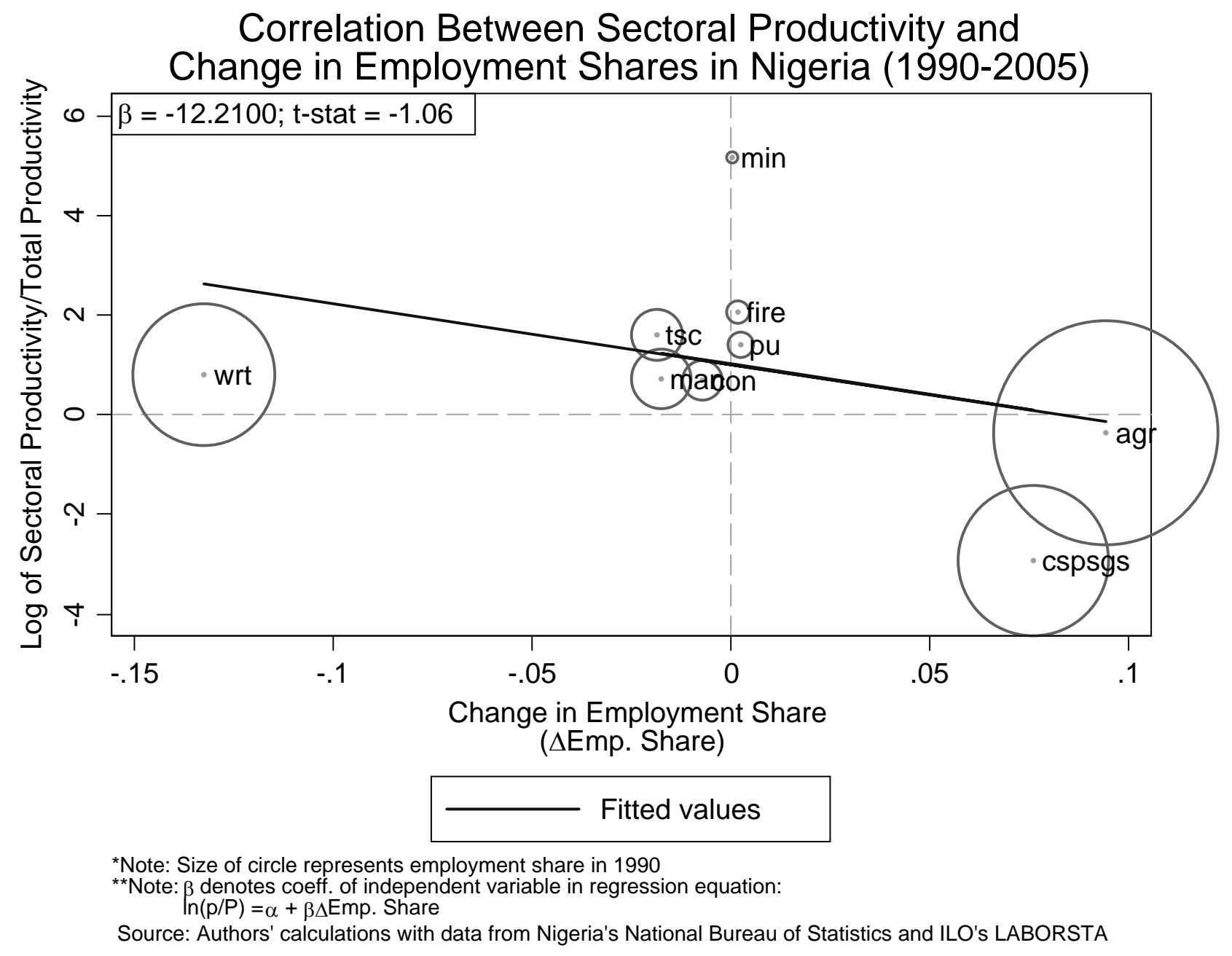

Figure 12

Note: Abbreviations are as follows: (agr) Agriculture; (min) Mining; (mfg) Manufacturing; (pu) Public Utilities; (con) Construction; (wrt) Retail and Wholesale Trade; (tsc) Transport and Communication; (fire) Finance and Business Services; (cspsgs) Community, Social, Personal and Government Services. 


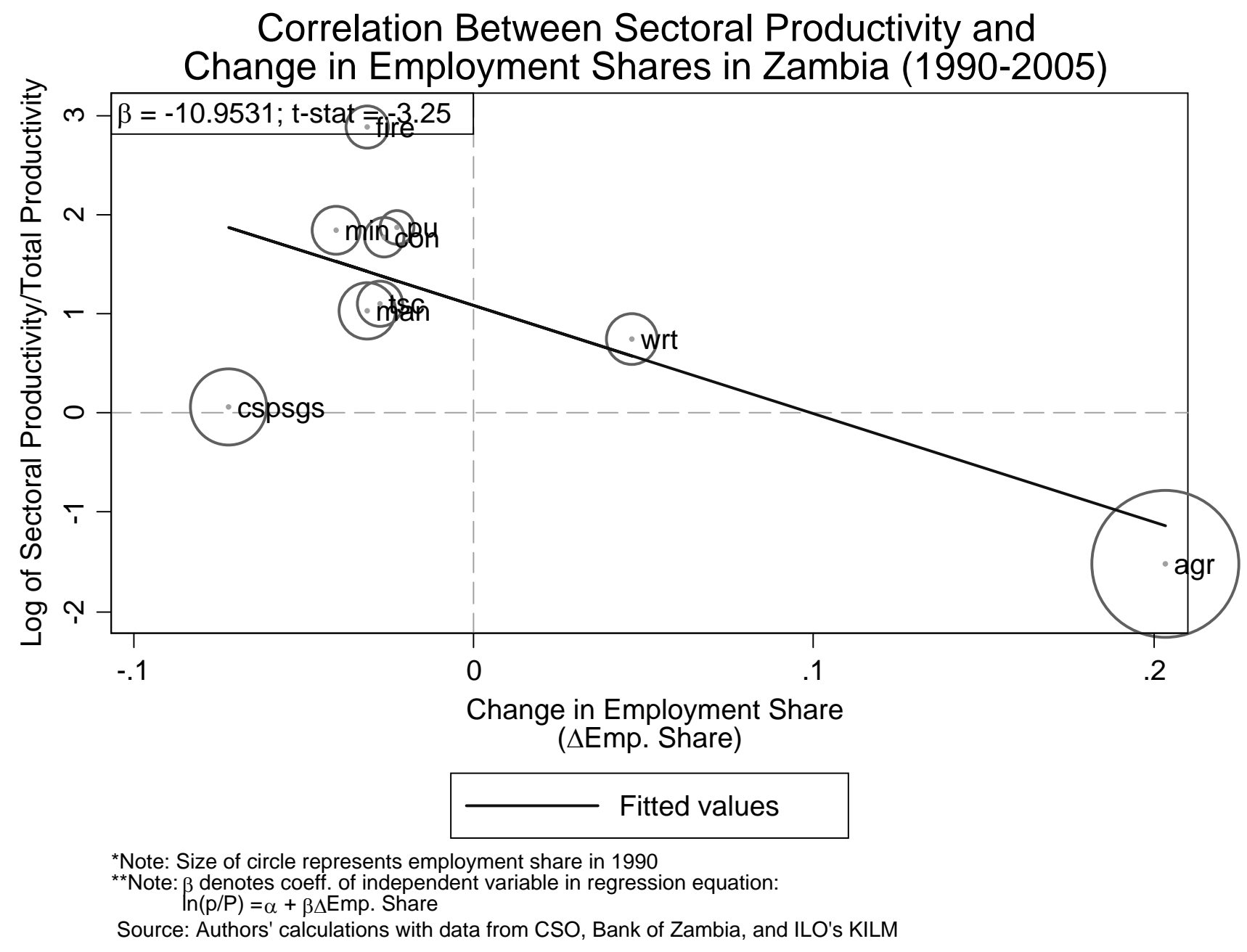

Figure 13

Note: Abbreviations are as follows: (agr) Agriculture; (min) Mining; (mfg) Manufacturing; (pu) Public Utilities; (con) Construction; (wrt) Retail and Wholesale Trade; (tsc) Transport and Communication; (fire) Finance and Business Services; (cspsgs) Community, Social, Personal and Government Services. 


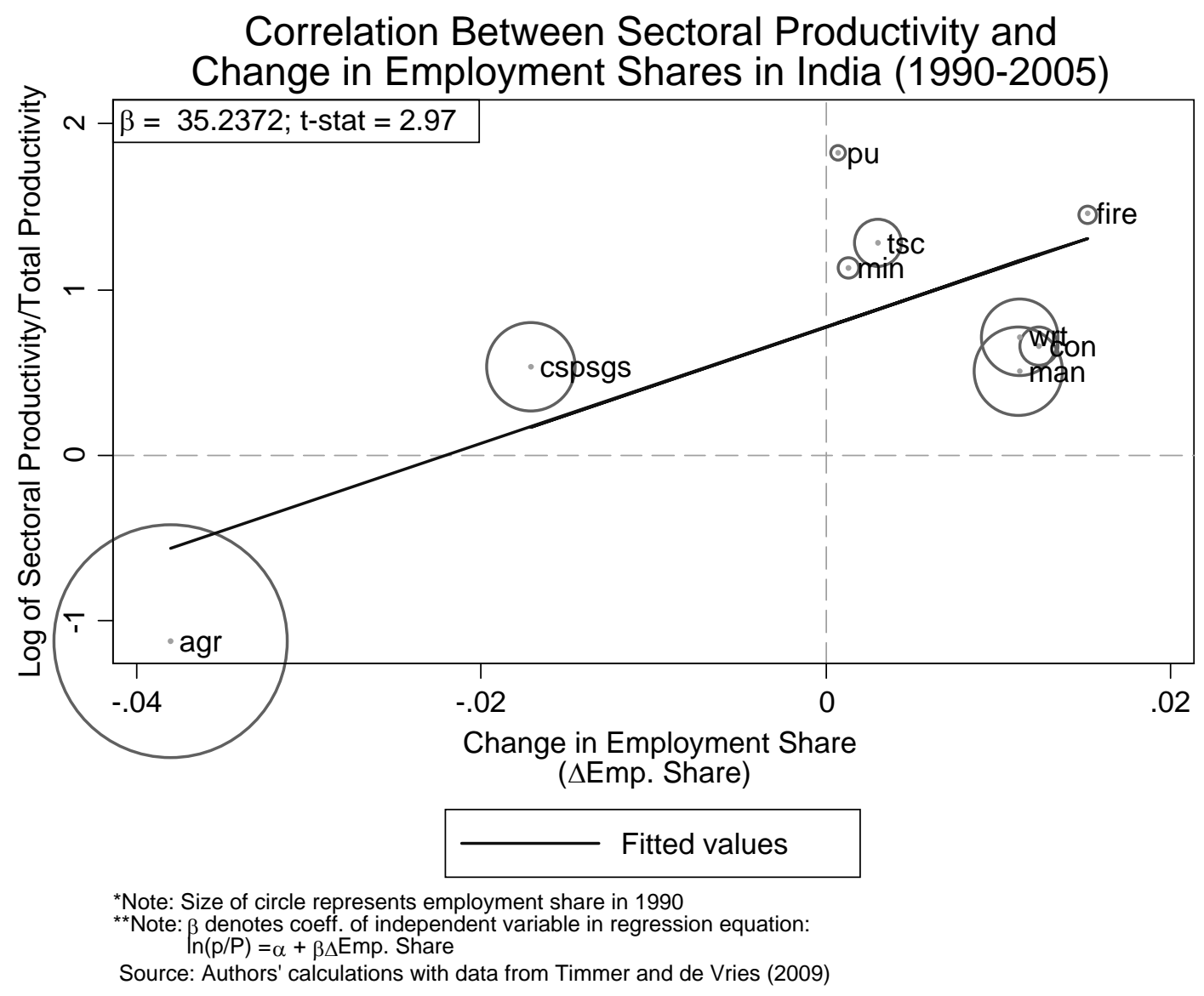

Figure 14

Note: Abbreviations are as follows: (agr) Agriculture; (min) Mining; (mfg) Manufacturing; (pu) Public Utilities; (con) Construction; (wrt) Retail and Wholesale Trade; (tsc) Transport and Communication; (fire) Finance and Business Services; (cspsgs) Community, Social, Personal and Government Services. 


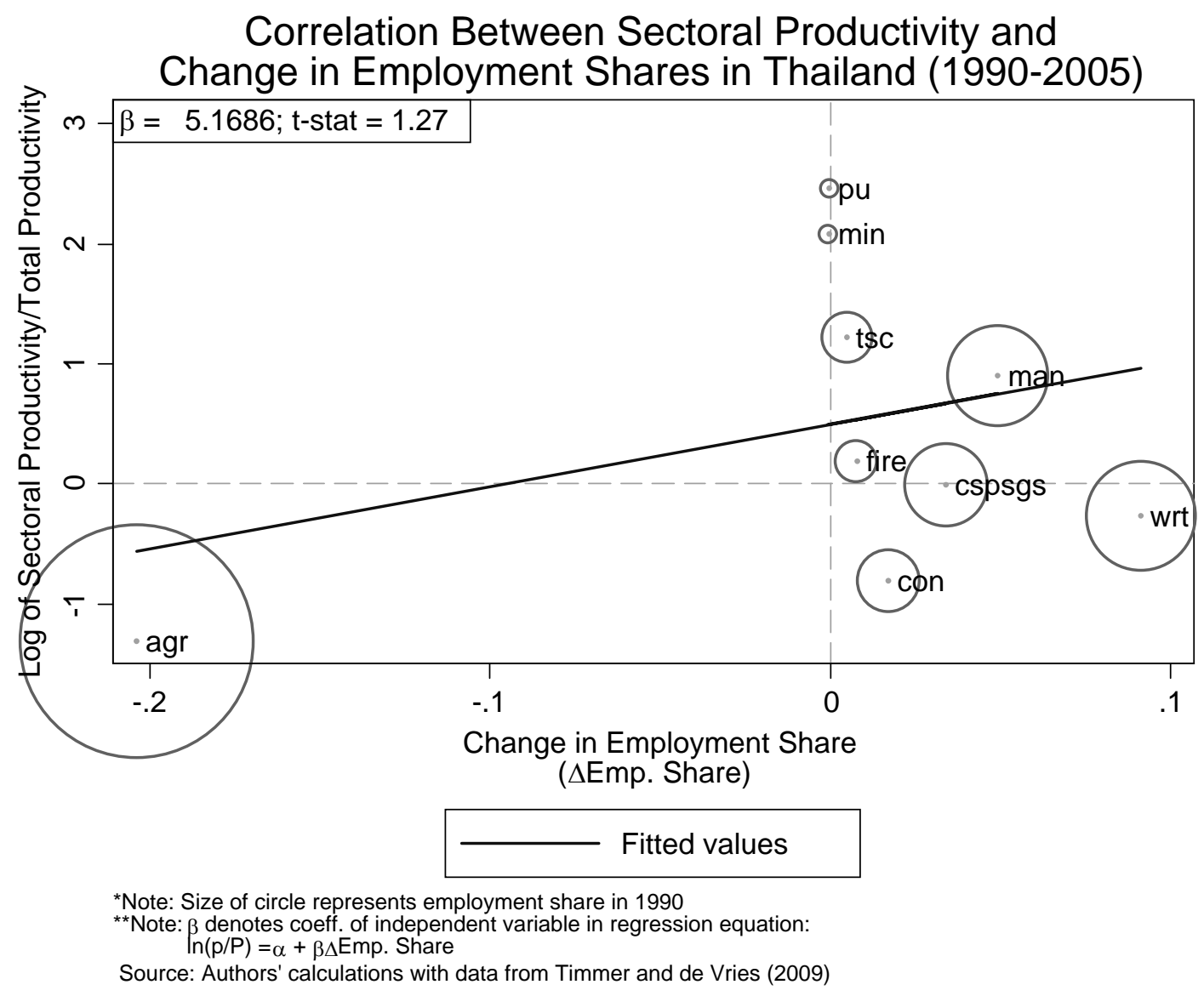

Figure 15

Note: Abbreviations are as follows: (agr) Agriculture; (min) Mining; (mfg) Manufacturing; (pu) Public Utilities; (con) Construction; (wrt) Retail and Wholesale Trade; (tsc) Transport and Communication; (fire) Finance and Business Services; (cspsgs) Community, Social, Personal and Government Services. 